\title{
Virulence and Pathogenicity Properties of Aggregatibacter actinomycetemcomitans
}

\author{
Georgios N. Belibasakis ${ }^{1}{ }^{\mathbb{D}}$, Terhi Maula ${ }^{2}$, Kai Bao ${ }^{1}$, Mark Lindholm ${ }^{3}$, Nagihan Bostanci ${ }^{1}$, \\ Jan Oscarsson ${ }^{3}$ (D) Riikka Ihalin ${ }^{2}$ iD and Anders Johansson ${ }^{3, *}$ (D) \\ 1 Division of Oral Diseases, Department of Dental Medicine, Karolinska Institutet, S-141 04 Huddinge, \\ Sweden; george.belibasakis@ki.se (G.N.B.); kai.bao@ki.se (K.B.); nagihan.bostanci@ki.se (N.B.) \\ 2 Department of Biochemistry, University of Turku, FI-20014 Turku, Finland; terhi.maula@utu.fi (T.M.); \\ riikka.ihalin@utu.fi (R.I.) \\ 3 Department of Odontology, Umeå University, S-901 87 Umeå, Sweden; mark.lindholm@umu.se (M.L.); \\ jan.oscarsson@umu.se (J.O.) \\ * Correspondence: anders.p.johansson@umu.se; Tel.: +46-90-7856291
}

Received: 27 September 2019; Accepted: 4 November 2019; Published: 6 November 2019

check for updates

\begin{abstract}
Aggregatibacter actinomycetemcomitans is a periodontal pathogen colonizing the oral cavity of a large proportion of the human population. It is equipped with several potent virulence factors that can cause cell death and induce or evade inflammation. Because of the large genetic diversity within the species, both harmless and highly virulent genotypes of the bacterium have emerged. The oral condition and age, as well as the geographic origin of the individual, influence the risk to be colonized by a virulent genotype of the bacterium. In the present review, the virulence and pathogenicity properties of A. actinomycetemcomitans will be addressed.
\end{abstract}

Keywords: Aggregatibacter actinomycetemcomitans; leukotoxin; cytolethal distending toxin; lipopolysaccharides; cytokine binding factors; horizontal gene transfer; outer membrane vesicles; biofilm; proteomic

\section{Introduction}

Aggregatibacter actinomycetemcomitans is a facultative anaerobic Gram-negative bacterium that expresses several virulence factors, which activates a host response that could be associated to the pathogenesis of periodontitis [1]. This review will elaborate in more detail the virulence properties of A. actinomycetemcomitans that contribute to the increased pathogenicity of this species, particularly with regard to early and rapidly progressive forms of periodontal disease [2,3], such as localized aggressive periodontitis, where it is frequently a predominant find (Figure 1). The "crown jewel" of the virulence factors of $A$. actinomycetemcomitans has long been its leukotoxin [4,5]. However, a cytolethal distending toxin (CDT) has also been identified, making this species the only member of the oral microbiome to produce these two, or any of the two, protein exotoxins [6]. Its lipopolysaccharide is quite special in that the immunological responses elicited by the host can be used in classifying (serotyping) the virulence identity of each one of its strains [7]. More recently identified cytokine-binding molecules add to its potential virulence factors, suggesting additional pathogenicity mechanisms by which it can manipulate the host [8]. A. actinomycetemcomitans is also equipped with a wealth of outer membrane vesicles, like all Gram-negative species, which might confer special virulence properties to this species [9]. There is a great genetic diversity within this species, with base composition biases in the genomic islands suggesting their acquisitions via horizontal gene transfer [10]. Recent advances in biofilm modeling and proteomic technologies have helped define the localization of A. actinomycetemcomitans within biofilms, characterize the full range of its protein components, and define how these are regulated 
by other species, and vice versa, when growing within complex polymicrobial communities [11]. Increased knowledge about bacterial virulence markers in periodontal disease may be important tools in future strategies for personalized dentistry [12].
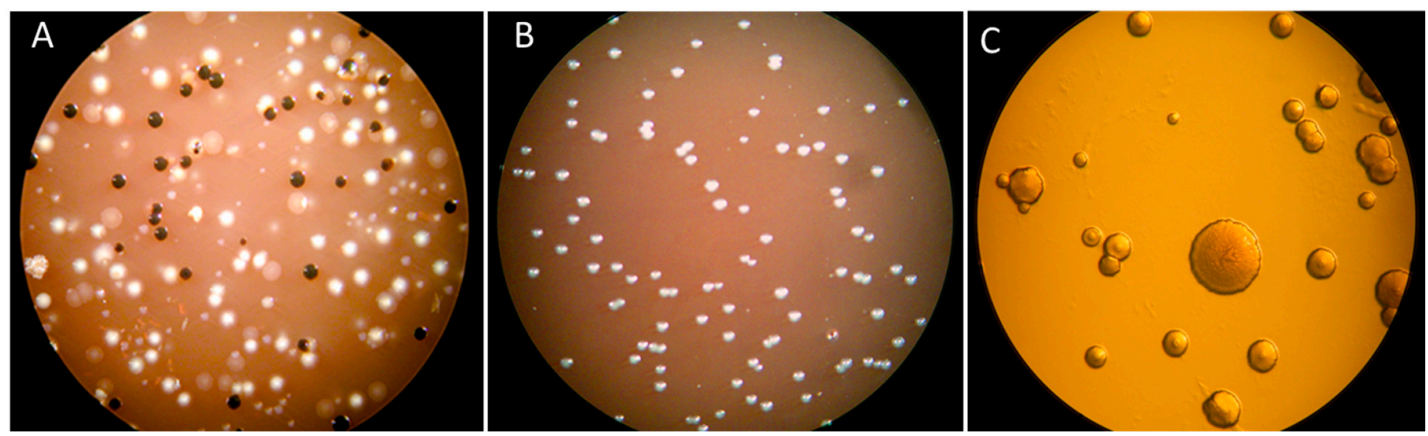

Figure 1. Subgingival biofilm samples from pathological periodontal pockets cultivated on blood agar plates for $48 \mathrm{~h}$ at $37^{\circ} \mathrm{C}$ in an anaerobic atmosphere. (A) Sample obtained from a periodontal pocket of a middle-aged patient diagnosed with generalized chronic periodontitis. The macroscopical observation of the plated sample showed occurrence of a variety of colonies corresponding to different bacterial species. (B) Sample obtained from a periodontal pocket of a 25-year-old patient diagnosed with localized aggressive periodontitis. The macroscopical observation of the plated sample showed predominantly the occurrence a single colony type. (C) Microscopical (50× magnification) examination indicated that all colonies belonged to the A. actinomycetemcomitans species, which was confirmed in assays based on genetic characterization.

\section{Leukotoxin (LtxA)}

The leukotoxin (LtxA) of A. actinomycetemcomitans affects the different leukocyte populations with various death mechanisms [4]. It activates neutrophil degranulation causing a massive release of lysosomal enzymes, net-like structures, and matrix metallo proteinases (MMPs) and induces apoptosis in lymphocytes [13-15]. Interestingly, net-like structures can also be released from the LtxA-exposed neutrophils under anaerobic conditions and contain citrullinated proteins with sequence homology to proteins found in inflamed joints [16,17]. In the monocytes/macrophages, the toxin activates the inflammasome complex including the cysteine proteinase caspase- 1 , which induces an activation and secretion of the pro-inflammatory cytokines IL-1 $\beta$ and IL-18 $[2,18,19]$. These cellular and molecular mechanisms have been previously described in detail [20] (Figure 2). Taken together, several of the mechanisms by which LtxA affects leukocytes are also involved in the pathogenic mechanisms of many inflammatory disorders, such as periodontitis [21]. LtxA show a high target cell specificity expressed and affect only cells of hematopoetic origin from humans and some other primates [5]. This species-specificity of LtxA is reported to act through a unique target cell receptor and a specific region in the toxin that recognizes and interacts with this receptor [22,23]. A region of LtxA contains a series of 14 tandemly repeated amino acid sequences in the repeat region of the toxin and are shown to be responsible for the receptor binding to Lymphocyte function-associated antigen 1 (LFA-1) [4,23]. The LFA-1 molecule is a heterodimer consisting of the $\alpha \mathrm{L}$ (CD11a) and $\beta 2$ (CD18) subunits and is suggested to help the toxin to have a correct orientation on the target cell membrane [24-27]. 


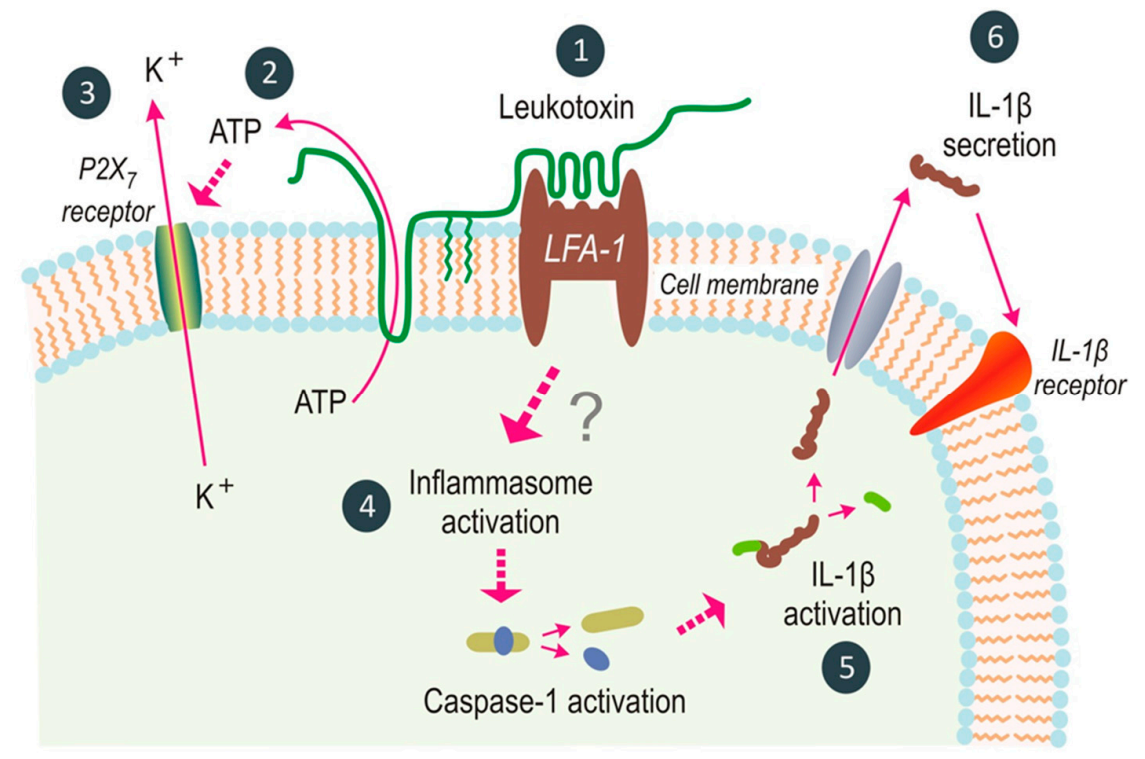

Figure 2. Leukotoxin (LtxA) induces a rapid inflammatory cell death in human macrophages. Briefly, LtxA binds to the LFA-1 receptor (1) and induces an extracellular release of ATP (2), which act as a ligand for the P2X7-receptor and result in an efflux of potassium (3). These processes promote the formation of an inflammasome multimer (4) that activates the cysteine proteinase caspase-1, resulting in a rapid activation (5) and secretion of IL-1 $\beta$ (6). Courtesy of Haubek and Johansson [20].

\subsection{LtxA Production}

The LtxA operon belongs to the core genome of A. actinomycetemcomitans and is so far present in all examined strains [28]. The operon consists of four coding genes named $l t x C, l t x A, l t x B$, and $l t x D$ and an upstream promoter region [29]. The gene $l t x A$ encodes the LtxA protein, $l t x C$ a protein required for the posttranslational acylation of LtxA, and $l+x B$ and $l+x D$ proteins needed for the transport of the LtxA to the bacterial outer membrane. For regulation of the LtxA expression, there is a promoter region located upstream of the $l t x C$ gene, and genetic differences within this region result in different genotypes with various LtxA expression [10].

Zambon [30] reported that leukotoxicity of A. actinomycetemcomitans isolated from individuals with periodontitis was enhanced compared with isolates from individuals without periodontitis. Later, it was discovered that many of the isolates with enhanced leukotoxicity have been shown to have a different type of promoter in the leukotoxin operon [29]. A specific genotype (JP2) of A. actinomycetemcomitans with enhanced leukotoxicity has been shown to significantly correlate to disease onset in infected individuals [31,32]. The JP2 genotype was first identified by Brogan and co-workers [33] and was a serotype b isolate with a 530 base pair (bp) deletion in the ltxCABD promoter. Based on this finding, isolates with such a deletion in the promoter are named JP2 genotype, and those lacking this deletion are non-JP2 genotype [20,34]. The discovery of the JP2 genotype introduced a new terminology of high and low leukotoxic A. actinomycetemcomitans based only on the ltx promoter type $[33,35]$. The presence of the JP2 genotype is highly associated to adolescents of North and West African origin [31,36]. However, the JP2 genotype has recently been shown to also colonize individuals of other geographic origin, as confirmed by genotyping [37,38]. Alterations in the ltx promoter region are the most studied genotypes associated with enhanced LtxA expression. In addition to the JP2 genotype, an insertion of $886 \mathrm{bp}$, as well as a $640 \mathrm{bp}$ deletion in the ltx promoter, has been discovered in A. actinomycetemcomitans isolates [39,40]. These three different genotypes are all associated with high virulence due to enhanced production of LtxA. Whether the deletions or insertions per se are causing the increased leukotoxin production is not entirely clear.

Enhanced leukotoxicity has been reported from serotype $b$ isolates with an intact ltx promoter region, indicating a high production of the toxin [41]. These isolates represent a subgroup of serotype $b$ 
with a high association with disease progression in the infected individual. Genetic characterization of this subgroup showed a genetic pattern with similarities to that of the JP2 genotype, and such strains are frequently carried by young individuals with periodontitis [2,38,42]. A specific genetic marker (cagE) correlates to A. actinomycetemcomitans with enhanced leukotoxicity, including the JP2 genotype and other virulent serotype $b$ isolates [42,43]. Interestingly, the activity of LtxA has been reported to be involved in induction of systemic autoantibodies to citrulline, which are risk markers for rheumatoid arthritis $[17,44]$. In addition, LtxA has a crucial role in sepsis induced by bacteremia in an animal model [45].

\subsection{Leukotoxin Secretion}

The secretion of LtxA is mediated by a Type I secretion system in line with other proteins of the repeat in toxin (RTX family) expressed by several Gram-negative pathogens [46-48]. A unique property for LtxA among the RTX proteins is that the secreted toxin is reported to be associated to the bacterial outer membrane [47]. The export of the toxin to the bacterial outer membrane has been shown to require expression of three proteins- $\mathrm{LtxB}, \mathrm{LtxD}$, and TdeA-for export of the toxin to the bacterial outer membrane, and a fourth-LtxC—for the acylation [49]. In addition, the inner membrane protein MorC, which affects the outer membrane structure, has been reported to be necessary for efficient export of the toxin [50]. The localization of LtxA was found to be on the outside of the bacterial membrane and on vesicles associated to the outer membrane [51,52]. The responsible mechanisms for the association of LtxA to the membrane are still not fully clarified, and whether the secreted LtxA remains associated to the bacterial outer membrane or is released to the environment is a topic of controversy. A suggestion is that the hydrophobic domain of LtxA mediates the association to the bacterial membrane [27]. Ohta and co-workers [53,54] reported that LtxA could be released from the bacterial membrane by DNase or RNase treatment, which indicates involvement of electrostatic forces between the negatively charged nucleic acid and the positively charged LtxA. This phenomenon was later supported by the observation that LtxA on the bacterial membrane and on vesicles was released in hypertonic $\mathrm{NaCl}$ solutions [55]. LtxA was also released from the bacterial membrane in presence of serum proteins, which indicates involvement of competitive mechanisms [56]. Differences in the culture media have been shown to determine the distribution of the produced LtxA between the bacterial outer membrane and the culture supernatant [56-58]. Whether LtxA is associated with the bacterial membrane or released to the environment at the infected site in vivo is still not known. However, the serum mediated release of the LtxA [56], as well as the activation of a systemic immunogenic response [59,60], indicates a release of LtxA from bacteria growing in an in vivo oral biofilm.

The secreted LtxA has been shown to be efficiently inactivated by proteases and superoxide radicals [55,61,62]. In 1981, McArthur and co-workers reported that the activity of LtxA in interaction with polymorphonuclear leukocytes (PMNs) was enhanced in the presence of human serum [63]. This phenomenon could later be explained by the protective effect of the serum protease inhibitors on the proteolytic enzymes released from LtxA challenged PMNs that degrades the toxin [56,64].

\subsection{Quantification of LtxA Production}

The great genetic diversity of A. actinomycetemcomitans has resulted in various genotypes with substantially different virulence properties, i.e., LtxA production $[10,28]$. The expression of LtxA is also influenced by environmental factors, such as growth conditions and substrates [46]. Notably, an anaerobic culture condition enhances substantially the production of LtxA, which mirrors the condition in the periodontal pocket [65].

Due to the complex regulation of $l t x A$ expression, the balance between membrane-associated and secreted toxin, as well as its sensitivity to proteolytic degradation, a gold standard for quantification of LtxA production, is still not available. The first attempt to quantify LtxA activity was to add bacteria to isolated leukocytes and determine cell death by trypan blue exclusion [66]. In a study by Zambon and co-workers [67], the leukocyte lysis method was used to discriminate between leukotoxic 
and non-leukotoxic strains. This study showed that the prevalence of more leukotoxic variants of A. actinomycetemcomitans was higher in young individuals with periodontitis than in older individuals with the disease or in periodontally healthy individuals.

Except for examining the leukotoxicity of the isolates, methods targeting gene expression or immunodetection have been developed $[58,68]$. These methods have been employed on a limited number of A. actinomycetemcomitans isolates and support findings from previous leukotoxicity determinations, with enhanced expression in the JP2 genotype [69,70]. To obtain a gold standard for quantification of leukotoxicity of isolated A. actinomycetemcomitans is one of several challenges for future research.

\section{Cytolethal Distending Toxin (CDT)}

The CDT family comprises a number of bacterial protein exotoxins that is expressed by several Gram-negative species. Due to its deleterious effects on the host, as revealed in various experimental models, CDTs are likely to be involved in the etiopathogenesis of the associated human infections. They can be described as genotoxins, as their main action is to elicit DNA damage upon the intoxicated host cells [71]. The CDT holotoxin consists of subunits CdtA, CdtB, and CdtC. While CdtA and $\mathrm{CdtC}$ subunits mediate the internalization of the CdtB into the cell, the latter is translocated to the nucleus, causing its deleterious effects on the host cells. This subunit is functionally homologous to deoxyribonuclease I, hence it can cause DNA damage. It is postulated that CdtB internalization occurs via a mechanism involving the recognition of cell membrane cholesterol by both $\mathrm{CdtC}$ and $\mathrm{CdtB}[72,73]$.

A. actinomycetemcomitans expresses a CDT and is the only known oral species with this property. An estimated $66 \%$ to $86 \%$ of its strains express a CDT, and its presence has been associated with the occurrence of periodontal disease [74]. It is very plausible that its pathogenic effects are related to its capacity to cause DNA damage, cell cycle arrest, and eventually apoptosis to the intoxicated cells. This has been shown in structural cells like gingival fibroblasts and periodontal ligament cells $[75,76]$, gingival epithelial cells [77-80], or gingival tissue explants [79], denoting that it can compromise the structural integrity and homeostatic capacity of the tissues. The capacity of CDT to affect the gingival epithelium has also been shown in human gingival explants [81], as well as in vivo upon inoculation of the toxin on rat gingival tissue [82]. Cells of the immune system are also highly susceptible to the cell cycle-arresting and apoptotic action of CDT, as has been demonstrated in human T cell [83], B-cells [84], and mononuclear cells [85]. CDT may also subvert the phagocytic capacity of macrophages and subvert their cytokine producing capacity [85]. The deleterious effects of CDT on cells of the immune system denote an impairment of the local immunity, which may compromise the capacity of the periodontium to recognize and eliminate the bacterial challenge, be it A. actinomycetemcomitans or other microbial constituents of the biofilm community.

Another potentially pathogenic mechanisms activated by CDT is the stimulation of pro-inflammatory and osteolytic cytokine production by the intoxicated host cells [86]. It has been shown that CDT can stimulate the production of pro-inflammatory cytokines by peripheral blood mononuclear cells, such as interferon (IFN)- $\gamma$, Interleukin (IL)-1 $\beta$, IL-6, and IL-8, a virulence property potentially independent of the toxin's deoxyribonuclease I activity [85]. However, A. actinomycetemcomitans can stimulate the production of several pro-inflammatory cytokines and regulate inflammasome expression irrespective of its CDT, as demonstrated by the use of the CDT-deletion strains $[87,88]$. An important virulence property of $\mathrm{CDT}$ is revealed by its capacity to induce the major osteolytic factor receptor activator of nuclear factor kappa-B ligand (RANKL). This is a crucial molecule that stimulates the differentiation of osteoclasts and, consequently, bone resorption in periodontitis [89]. It has been shown that CDT induces RANKL expression and production in periodontal connective tissue cells, such as gingival fibroblasts and periodontal ligament cells [90,91], as well as T-cells [92]. This implies that the CDT may increase the levels RANKL in the periodontal tissues and therefore potentiate bone destruction by this action. The induction of inflammatory and bone-destructive molecular 
cascades in the periodontium by CDT may well constitute an additional mechanism through which A. actinomycetemcomitans is involved in the etiopathogenesis of periodontitis. On the other side of the bone remodeling equilibrium, when CDT acts directly on pre-osteoclasts, it may also induce apoptosis and hinder their differentiation to osteoclastic cells, thereby contributing a dysbalanced bone remodeling equilibrium that leads to periodontal breakdown [93].

\section{Lipopolysaccharide and Cytokine-Binding Factors}

\subsection{The Virulence Properties of A. actinomycetemcomitans Lipopolysaccharide}

Like other Gram-negative species, A. actinomycetemcomitans surface is covered by lipopolysaccharide (LPS), a potent pro-inflammatory molecule. A. actinomycetemcomitans LPS comprises a group of structurally related molecules in which the $\mathrm{O}$-specific polysaccharide chain (O-antigen), formed by oligosaccharide repeating units, is the most variable portion (Figure 3).

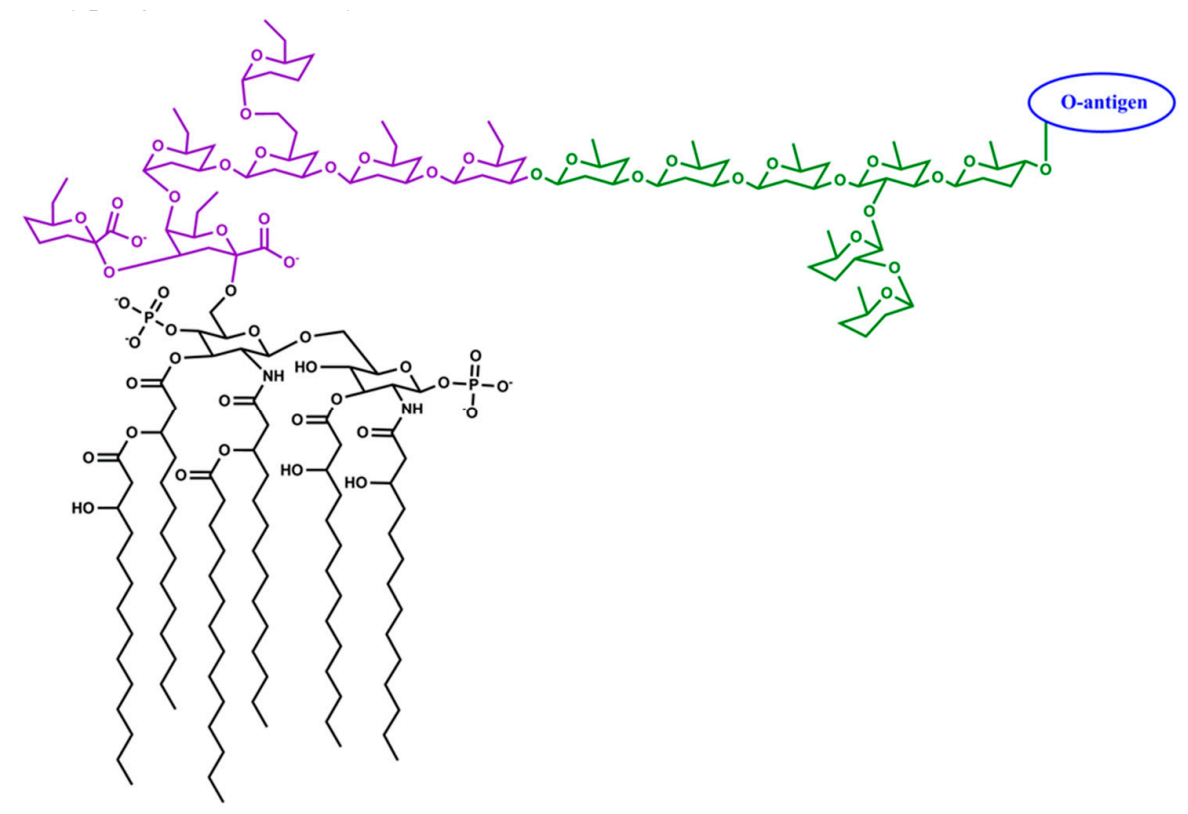

Figure 3. Schematic representation of a putative structure of the lipid A and the core oligosaccharides of A. actinomycetemcomitans lipopolysaccharide (LPS). The lipid A (black) of A. actinomycetemcomitans LPS is formed by four primary fatty acyl chains (myristic or 3-hydroxymyristic acid) linked by ester and amide linkages to a disaccharide of glucosamine. Two of the primary fatty acyl chains are esterified by secondary fatty acids. The acylation pattern of lipid A is asymmetric with four fatty acyl chains on the non-reducing glucosamine and two on the reducing glucosamine. The inner core (purple) is linked to lipid A by a ketosidic bond and is formed by 3-deoxy-D-manno-oct-2-ulosonic acid (Kdo) together with heptose residues such as glycero-manno-heptose. The outer core (green) usually consists of hexoses such as glucose and galactose. Functional groups such as hydroxyl and phosphate groups are common substituents in the lipid A and the core oligosaccharides. The O-specific polysaccharide chain (O-antigen) is the most variable portion in the LPS. The O-antigen consists of a large variety of sugar residues in many combinations and glycosidic linkages. For simplicity, substituents such as hydroxyl and phosphate groups (other than those in lipid A), conformational details of the monosaccharide residues, and the stereochemistry of the glycosidic bonds are not presented.

The serotyping of A. actinomycetemcomitans to seven different serotypes from a to $\mathrm{f}$, as well as to non-serotypeable, is based on the structural differences in the O-antigen part of LPS. Commonly found monosaccharide residues in the A. actinomycetemcomitans $\mathrm{O}$-antigen include the hexoses glucose, galactose, mannose, and talose; the hexosamines glucosamine and galactosamine; and the deoxyhexoses rhamnose and fucose. However, between different A. actinomycetemcomitans strains, there appears to 
be significant variation in the final architecture of the oligosaccharide repeating units, which may be either di-, tri-, or tetrasaccharide moieties [94-97]. Thus, variation in the gene clusters involved in the synthesis of the highly variable polysaccharide moieties serves as the basis for PCR serotyping of A. actinomycetemcomitans strains $[94,98]$.

The structures of the core oligosaccharide and the lipid A in A. actinomycetemcomitans LPS have a lower degree of structural freedom than the $\mathrm{O}$-antigenic polysaccharides. The core oligosaccharide consists of 3-deoxy-D-manno-oct-2-ulosonic acid (Kdo), glycero-manno-heptose, glucose, and galactose, and appears conserved among different serotypes $[96,97]$. The lipid A consists of two phosphorylated glucosamine residues $[96,97]$ and primarily myristic and 3-hydroxymyristic acid as the fatty acyl chains [97,99-102]. Amino compounds such as ethanolamine and glycine are found associated with A. actinomycetemcomitans lipid A and core oligosaccharides but in fewer numbers than the commonly found hydroxyl and phosphate group substituents [97]. A. actinomycetemcomitans growth is favoured in slightly alkaline environments $[103,104]$ in which the phosphate groups and the Kdo occur in deprotonated form. The phosphate groups and the Kdo interact with positively charged ions and participate in hydrogen bonding, and thus contribute to the stabilization of the bacterial outer membrane.

The fatty acyl composition of lipid A generally varies between different Gram-negative species. For example, in lipid A of Escherichia coli and Salmonella typhimurium LPS the relative amount of myristic acid is lower than in A. actinomycetemcomitans LPS, while lauric acid and palmitic acid are more frequently found [100]. The lipid A composition of closely related species may not always be specific enough to allow taxonomic differentiation, as demonstrated by the similar composition of A. actinomycetemcomitans and Aggregatibacter aphrophilus lipid A [100]. Closely related species may, however, be differentiated by the composition of their (core) oligosaccharides. A distinct feature of the oligosaccharides of A. actinomycetemcomitans is the presence of both Dand L-glycero-D-manno-heptose, whereas A. aphrophilus LPS only contains the L-enantiomer of this aldoheptose $[105,106]$. By contrast, galactose appeared twice as abundant in LPS from A. aphrophilus as in LPS from A. actinomycetemcomitans $[99,105,106]$.

Although there are several studies that indicate a distinct effect of $A$. actinomycetemcomitans LPS on rodent cells [107-111], we will focus here on describing how A. actinomycetemcomitans LPS stimulates human cells. This outlining is done due to the known differences between the murine/rat and human immune systems [112]. The various virulence-related effects of A. actinomycetemcomitans LPS are summarized in Table 1. The first cells encountered by detached A. actinomycetemcomitans LPS in junctional epithelium (JE) of a tooth are the epithelial cells. These human epithelial cells have been shown to respond to A. actinomycetemcomitans LPS by expressing IL-15 which results in enhanced IFN- $\gamma$ production and proliferation of human T cells [113]. Moreover, A. actinomycetemcomitans LPS causes widening of the intercellular spaces in primary tissue cultures mimicking the JE, a phenomenon not observed with Porphyromonas gingivalis LPS [113]. Various direct effects of A. actinomycetemcomitans LPS on the other main human gingival cell type, fibroblasts, have also been reported. Collagen is ingested and digested by gingival fibroblasts in balanced conditions of healthy gingiva. A. actinomycetemcomitans LPS is able to enhance the phagocytosis of collagen by fibroblasts which may result in imbalance in regeneration of the gingival tissue [114]. In addition to changes in cellular functions, A. actinomycetemcomitans LPS stimulate the production of IL-6 and IL-8 [114], tissue plasminogen activator (t-PA), and plasminogen activator inhibitor 2 (PAI-2) by human gingival fibroblasts [115]. The plasminogen/plasmin system is involved in the complex process of extracellular matrix degradation and renewal in the gingival tissue, a step that most likely precedes the collagen phagocytosis by the gingival fibroblasts.

Gingival tissue contains various resident immune cells, of which macrophages play a central role in periodontitis. A. actinomycetemcomitans LPS has shown to stimulate the expression of microRNA miR-146a [116], which downregulates the expression of TNF receptor-associated factor 6 and IL-1 receptor-associated kinase 1 , which serves as a negative feedback loop in cytokine signaling [117]. 
On the contrary, high doses of A. actinomycetemcomitans LPS downregulated the expression of miR-32 and miR-29b, which target the pro-apoptotic factor Bim of acute myeloid leukemia cells [118] and IL-6 receptor $\alpha$ [117], respectively. Another human cell type that originates from mesenchymal stem cells is osteoblast which plays a significant role in bone formation. A. actinomycetemcomitans LPS has capacity to increase the inducible nitric oxide synthase (iNOS) activity and induce the nitric oxide (NO) production by human osteoblast-like cell line [119]. If osteoblasts produce NO rapidly, when responding to bacterial infection, it may lead to bone resorption [120].

Table 1. Virulence-related properties of A. actinomycetemcomitans LPS.

\begin{tabular}{ccc}
\hline Target & Effect & Reference \\
\hline Epithelial cells & IL-15 expression, widening of the intercellular spaces & {$[113,121]$} \\
\hline Gingival fibroblasts & $\begin{array}{c}\text { Enhancement of collagen phagocytosis, increase the } \\
\text { production of IL-8, IL-6, t-PA, PAI-2 }\end{array}$ & {$[114-116,122]$} \\
\hline Macrophages & $\begin{array}{c}\text { Upregulation of miR-146a and downregulation of } \\
\text { miR-32 and miR-29b microRNAs }\end{array}$ & \\
\hline Osteoblasts & Increases iNOS activity and induce NO production & {$[119,123,124]$} \\
\hline Dendritic cells & Production of IL-12, IFN- $\gamma$, TNF- $\alpha$, IL-1 $\beta$, IL-6, \\
and IL-23 & \\
\hline PMN & Induce ROS production, stimulate IL-1 $\beta$, TNF- $\alpha$, and \\
& $\begin{array}{c}\text { IL-6 production, downregulate surface expression of } \\
\text { L-selectin, upregulate the expression of } \beta 2-\text {-integrins }\end{array}$ & {$[125-128]$} \\
\hline Human hemoglobin & Binding & {$[129]$} \\
\hline Human IL-8 & Binding & {$[130]$} \\
\hline
\end{tabular}

Another type of resident immune cells in periodontium is dendritic cells (DCs), which are involved in antigen presenting to T cells. Conventional DCs originate from monocytes, like macrophages, and are called mDCs. Monocytes originating from localized aggressive periodontitis (LagP) patients, recently renamed molar-incisor pattern periodontitis with rapid progression [131], spontaneously give rise to mDCs [132]. A. actinomycetemcomitans LPS enhances the IL-12 production by mDCs leading to stimulation of IFN- $\gamma$ expression of natural killer cells and undetectable levels of IL-4, which together may cause the polarization of naïve T cells toward the Th1 type response [123]. There are differences of DCs stimulation potential of A. actinomycetemcomitans LPS originating from different serotypes, serotype $b$ LPS inducing the strongest production of IL-12, IFN- $\gamma$, TNF- $\alpha$, IL-1 $\beta$, IL-6, and IL-23 [124]. The differences in the response of DCs to serotype $b$ A. actinomycetemcomitans LPS compared to the response to other serotype LPS most likely causes Th1/Th17 type of $\mathrm{T}$ cell response in serotype $b$ related infection [133].

PMNs are innate immune cells which may play both defensive and destructive role in periodontitis [134]. Neutrophils produce reactive oxygen species (ROS) when responding to whole bacteria or their components. A. actinomycetemcomitans LPS has been shown to be more potent inducer of neutrophil ROS production than, for example, P. gingivalis or Prevotella intermedia LPS [125]. Moreover, A. actinomycetemcomitans LPS stimulate the production of inflammatory cytokines IL- $1 \beta$ and TNF- $\alpha$ by PMN more efficiently than P. gingivalis LPS [126], and in human whole blood, A. actinomycetemcomitans LPS causes higher production of the above mentioned cytokines as well as IL-6 than E. coli LPS [127]. A. actinomycetemcomitans LPS can shift the movement of monocytes and granulocytes from rolling to the passaging through the vascular wall by downregulating the surface expression of L-selectin and increasing the expression of $\beta 2$ integrins, respectively [128].

Despite the vast literature concerning the inflammatory related functions of A. actinomycetemcomitans LPS, this outer membrane linked polysaccharide has also functions related to bacterial physiology. The serotype specific O-antigen part of A. actinomycetemcomitans LPS takes part in the secretion of leukotoxin, since a serotype $b$ mutant with inactive $r m l C$ and altered 
O-antigen sugar composition, contained more cytoplasmic and membrane-bound leukotoxin, and secreted less leukotoxin than the wild-type serotype b strain [135]. Moreover, the O-antigen part of A. actinomycetemcomitans LPS may mediate direct adhesion to abiotic surfaces [7]. Besides abiotic surfaces, A. actinomycetemcomitans LPS interacts with host molecules, such as human hemoglobin [129] and IL-8 [136], which may facilitate the iron acquisition and disturbance of host defense, respectively.

\subsection{Sensing of Host Signal Molecules}

A. actinomycetemcomitans is one of the human pathogens that is able to bind host cytokines, such as IL-1 $\beta$, IL-8, and IL-6 $[137,138]$, and internalize them $[138,139]$, which leads to changes in the properties of biofilm, decreasing the metabolic activity [139], and changing the composition of the extracellular matrix $[136,138]$. Several potential bacterial proteins that may interact with human cytokines have been identified in A. actinomyctemcomitans, including intracellular ATP synthase subunit $\beta$ [139], histone like DNA binding protein HU [139], and outer membrane proteins bacterial interleukin receptor I (BilRI) [138,140] and secretin channel HofQ [136]. The majority of these proteins have other functions in the bacterial cell related to metabolism, gene regulation, and uptake of nutrients and DNA for horizontal gene transfer, a character of so called "moonlighting" bacterial proteins [1]. Interactions with the above mentioned proteins may result in the observed uptake of cytokines, decreased metabolic activity and potentially, although not yet proved, also changes in the gene expression profile of A. actinomycetemcomitans. Both Gram-positive Staphylococcus aureus [141] and Gram-negatives Pseudomonas aeruginosa [142] and Neisseria meningitidis [143] are able to respond to cytokines, such as IL-1 $\beta$, IFN- $\gamma$, IL-8, and TNF- $\alpha$, by changing their virulence gene expression pattern.

Human cytokines are not the only host signalling molecules that A. actinomyctemcomitans is able to bind and sense. A. actinomyctemcomitans harbours the two-component system QseCB, which has originally been detected from enterohemorrhagic Escherichia coli EHEC [144]. In EHEC, QseCB senses either endogenous autoinducer-3 or host catecholamine hormones epinephrine/norepinephrine and induces the expression of Locus of Enterocyte Effacement (LEE) vital for the virulence of EHEC [145]. However, A. actinomycetemcomitans needs also iron, in addition to catecholamine hormone, to activate the QseC sensor kinase [146]. The QseCB signalling changes the gene expression pattern of $A$. actinomycetemcomitans, and especially the genes needed for anaerobic metabolisms are upregulated [146]. Moreover, QseC plays role in the biofilm formation in a flow cell in vitro model, since $\triangle q s e C$ mutant strain forms significantly less biofilm in flow cells than the corresponding A. actinomyctemcomitans wild type and the complemented strains [147]. It is not known whether this impaired capacity to form biofilms also affects the virulence potential of A. actinomyctemcomitans in vivo. Yet, $\Delta q s e C$ mutant strain causes less bone loss in murine model of periodontitis than the wild-type strain, suggesting a strong link between A. actinomycetemcomitans QseC and virulence [147].

\section{Outer Membrane Vesicles}

During the latest decades it has become apparent that membrane vesicles (MVs) are naturally shed during growth by many bacteria, archaea, and eukaryotes. Membrane vesicles, also known as "Type Zero secretion", or referred to as outer membrane vesicles (OMVs) in Gram-negative organisms, serve as a general but relevant mechanism of antigen delivery, and are discharged by both commensal and pathogenic organisms in vivo and when infecting host cells in vitro [148,149]. Biologically active virulence factors such as CDT and OmpA can be transported into HeLa cells and human gingival fibroblasts via A. actinomycetemcomitans OMVs [150]. OMVs are also involved in the export of leukotoxin, peptidoglycan-associated lipoprotein (Pal), and the chaperonin GroEL to host cells [52,151-153]. Characterization of the OMV proteome of one A. actinomycetemcomitans clinical isolate using Matrix-Assisted Laser Desorption/Ionization Time of Flight-Mass Spectrometry (MALDI-TOF MS) revealed an array of additional tentative virulence-related proteins, including BilRI, Omp100, TdeA, and a ferritin-like protein $[154,155]$. This is in line with an OMV proteome exhibiting multiple offensive and defensive functions, such as drug targeting, iron acquisition, and immune 
evasion. A role of A. actinomycetemcomitans OMVs in serum resistance can be hypothesized based on observations that the vesicles could bind to the complement system regulator C4-binding protein in an OmpA-dependent manner [156]. Moreover, it has been shown that A. actinomycetemcomitans OMVs can transport small molecules such as those contributing to bone resorption, including LPS [157] and lipid A-associated proteins [158]. A. actinomycetemcomitans OMVs carry NOD1- and NOD2-active peptidoglycan, and upon vesicle internalization into non-phagocytic human cells such as gingival fibroblasts, the OMVs can act as an innate immunity trigger [9]. A. actinomycetemcomitans OMVs contain in addition nucleic acids [53], and recent evidence supports the concept that the OMVs can carry microRNA-sized small RNAs (msRNAs). These small RNAs might represent novel bacterial signaling molecules, which by means of OMVs can be transported into host cells to modulate the immune response [159]. A. actinomycetemcomitans OMVs appear to mainly internalize into host cells via clathrin-dependent endocytosis $[9,160]$ but can also fuse with host cell membranes in a cholesterol-dependent manner [150]. Toxins associated with OMVs can function as adhesins in receptor-mediated endocytosis of vesicles [161], but such a role of CDT or leukotoxin appears less likely, as neither of the toxins are required for the uptake of OMVs into host cells $[150,151]$. Additionally, despite the evident localization of leukotoxin on the surface of $A$. actinomycetemcomitans OMVs, there is no requirement of the toxin receptor LFA1 for vesicle-mediated trafficking of LtxA into host cells [162].

\section{Biofilm Interactions and Proteomic Regulations}

\subsection{Localization in Pocket and Tissue}

As a microaerophic organism, A. actinomycetemcomitans is able to grow both supragingivally and subgingivally, corresponding to aerobic and anaerobic growth, respectively. As it can be detected at both locations, it has been postulated that the environment of supragingival plaque harbouring A. actinomycetemcomitans can act as a reservoir for the spread or reinfection of this bacterium of subgingivally [163]. When growing subgingivally, A. actinomycetemcomitans is reported to be detected in the loosely attached unattached plaque area in the middle pocket zone [164]. Earlier histopathological studies determined the prevalence and gingival localization of A. actinomycetemcomitans in periodontal lesions of juvenile periodontitis patients (earlier classification), using culture techniques on disrupted tissue or immunofluorescence microscopy on intact tissue. The former demonstrated the presence of A. actinomycetemcomitans in almost all diseased tissues examined, with evidence of microcolonies and single bacterial cells within the gingival connective tissue, as well as inside the phagocytic cells within the tissue [165]. The latter demonstrated an increase in A. actinomycetemcomitans colony-forming units, which correlated with its presence in the tissue and in the periodontal pocket [165]. In situ hybridization studies have detected A. actinomycetemcomitans in epithelial cells from the lining gingival crevice [166] or in close relationship with the polymorphonuclear infiltrate of the pocket [167]. By quantitative real-time PCR of gingival tissue lysates, it was shown that $A$. actinomycetemcomitans is present at a higher prevalence in tissues of younger patients with aggressive periodontitis as compared to chronic periodontitis or health [168].

\subsection{Localization in Biofilms and Proteomic Interactions with Other Species}

Studies on the localization of A. actimomycetemcomitans in biofilms largely comes from in vitro models. In supragingival and subgingival biofilms, A. actinomycetemcomitans does not appear to affect the number of the other species present and appears to form small, dense, and secluded cell clusters of its own species throughout the biofilm mass $[169,170]$. Yet, the lack of numeric changes on other species of the biofilm does exclude the possibility that $A$. actinomycetemcomitans exerts regulatory proteomic and metabolic changes in the biofilm, as discussed further.

The development of mass spectrometry (MS) technology made it possible to identify multiple proteins in a single run. Therefore, it is a useful tool to study how A. actinomycetemcomitans orchestrates proteomic changes in the context of biofilms. Using 2D gels, Llama-Palacios et al. discovered 87 protein 
spots differently expressed $(1.5$-fold, $p<0.05)$ between planktonic and mono-species biofilm cultures of A. actinomycetemcomitans [171]. Then, using MALDI-TOF MS, 13 upregulated proteins (from 24 proteins spots) and 37 downregulated proteins (from 50 spots) were identified. The upregulated proteins were mainly outer membrane proteins involved the immunologic process, whereas downregulated proteins were related to the metabolism, biosynthesis, and transport. This is consistent with the finding that mature biofilms display increased virulence [172] despite lower metabolic activity [173] as compared to planktonic culture.

Because oral biofilms occur as complex polymicrobial communities, the study of A. actinomycetemcomitans within multispecies biofilms is highly relevant. When integrated within a 10-species subgingival biofilm model, A. actinomycetemcomitans did not significantly impact the abundance of the other bacterial species, nor did it affect the biofilm structure, which is consistent with findings in a supragingival biofilm model. Using liquid chromatography-tandem mass spectrometry (LC-MS/MS), 3225 and 3352 microbial proteins were identified in multi-species biofilms in the absence or presence of A. actinomycetemcomitans, respectively [170]. Further investigations with label-free quantification (LFQ) method displayed 728 bacterial proteins and found 483 of them to be differentially regulated (2-fold, $p<0.05$ ) among these two kinds of biofilms. Interestingly, the regulation trend for individual species was highly individual. For Prevotella intermedia, all quantified proteins were upregulated in the presence of $A$. actinomycetemcomitans, whereas the majority of the proteins were downregulated for Campylobacter rectus, Streptococcus anginosus, and P. gingivalis. These findings are well in line with the competing growth between $P$. gingivalis and A. actinomycetemcomitans, shown in a dual-species biofilm [174]. Furthermore, based on the GO analysis, A. actinomycetemcomitans appears to downregulate proteins with ferric iron binding functions and alter the metabolic rate for the overall biofilm.

To understand the effects of this A. actinomycetemcomitans-containing biofilms on host tissues, the biofilm model was introduced into a bioreactor-supervised 3D cell culture system, which consisted of epithelial and connective tissue structures to mimic the periodontium, as well as monocytes to stimulate the immune response [173]. As a result, S. anginosus, A. oris, V. dispar, C. rectus, and P. gingivalis were suppressed when present with the host tissue, while the tissue itself exhibited morphological, immunological, and proteomic changes. The numbers of $A$. actinomycetemcomitans in the biofilm were not reduced, but more of its proteins were expressed when co-cultured with the 3D (21 proteins) than the biofilm stand-alone (15 proteins) [173]. Yet, A. actinomycetemcomitans proteins only comprised a small fraction of all identified proteins in biofilm lysates (21 of 3363) and supernatants (one of 896).

Attachment to biotic surfaces or other biofilms enhances A. actinomyctemcomitans virulence properties. We have found that deletion of the gene $h n s$, encoding a histone-like family of DNA-binding, nucleoid-structuring protein (H-NS), a global gene silencer [179], leads to a less piliated phenotype of A. actinomycetemcomitans and decreases its biofilm formation ability when cultured as mono-species biofilms [11]. LFQ showed that the majority (29) of the differentially expressed proteins (2-fold, $p<0.05)$ were upregulated in the $h n s$ mutant biofilm, supporting the role of H-NS as gene suppressor in A. actinomyctemcomitans. Notably, the affected proteins included virulence factors such as leukotoxin $\mathrm{A}$ and D (LtxA and LtxD). A similar repression activity of H-NS for virulence factors from other microbes was observed on hemolysin operons hlyCABD [180] and ehxCABD [181] in E. coli and rtxACBD in Vibrio cholerae [182]. Within multi-species biofilms, using the hns mutant there was a significant reduction of $A$. actinomycetemcomitans numbers, without affecting the number of other species. On the protein level, LFQ data suggested that many Fusobacterium nucleatum and Streptococcus oralis proteins were downregulated in biofilm harbouring the wild-type A. actinomyctemcomitans strain, as compared to its hns mutant counterpart, and these proteomic regulations may occur long before the corresponding bacterial growth is affected. Most of the regulated proteins were associated with peptide metabolic process and regulation of translation, supporting a protein-orchestrating role of $\mathrm{H}-\mathrm{NS}$ in A. actinomycetemcomitans. 
A literature summary of the proteomic findings on A. actinomycetemcomitans in single-species biofilms and multi-species biofilms is provided in Tables 2 and 3, respectively.

Table 2. Proteomic studies on single species A. actinomycetemcomitans.

\begin{tabular}{|c|c|c|c|c|c|c|}
\hline Author & $\begin{array}{l}\text { Year } \\
\text { (Ref) }\end{array}$ & Brief Description & $\begin{array}{l}\text { Identified } \\
\text { Proteins * }\end{array}$ & $\begin{array}{c}\text { Proteomic } \\
\text { Application, Label } \\
\text { Free Quantification }\end{array}$ & Cutoff & PMID \\
\hline Llama-Palacios et al. & 2017 [171] & $\begin{array}{c}\text { A.a planktonic and } \\
\text { mono-species } \\
\text { biofilm cultures }\end{array}$ & 50 & 2DE, MALDI-TOF MS & N/A & 28707473 \\
\hline Kieselbach $\mathrm{T}$ et al. & 2016 [155] & $\begin{array}{c}\text { A.a outer membrane } \\
\text { vesicles dataset }\end{array}$ & 501 & $\begin{array}{l}\text { In solution digestion, } \\
\text { LC-MS/MS }\end{array}$ & $\begin{array}{l}\text { protein } \\
\text { FDR }<1 \%\end{array}$ & 28050585 \\
\hline Kieselbach T et al. & 2015 [154] & $\begin{array}{c}\text { A.a outer } \\
\text { membrane vesicles }\end{array}$ & 151 & $\begin{array}{l}\text { In solution digestion, } \\
\text { LC-MS/MS }\end{array}$ & $\begin{array}{l}\text { protein } \\
\text { FDR }<1 \%\end{array}$ & 26381655 \\
\hline Smith KP et al. & 2015 [175] & $\begin{array}{l}\text { A.a membrane } \\
\text { proteins related to } \\
\text { morphogenesis } \\
\text { protein C }\end{array}$ & 613 & $\begin{array}{l}\text { Stable-isotope } \\
\text { dimethyl labeling, } \\
\text { nanoscale LC-MS }\end{array}$ & $\mathrm{FP}<1 \%$ & 25684173 \\
\hline Smith KP et al. & 2015 [176] & $\begin{array}{l}\text { A. } a \text { membrane } \\
\text { proteins }\end{array}$ & 648 & $\begin{array}{l}\text { Stable-isotope } \\
\text { dimethyl labeling, } \\
\text { nanoscale LC-MS }\end{array}$ & $\mathrm{FP}<1 \%$ & 25055881 \\
\hline Zijnge $\mathrm{V}$ et al. & 2012 [177] & $\begin{array}{l}\text { A.a secreted proteins } \\
\text { from mono-species } \\
\text { biofilm }\end{array}$ & 179 & $\begin{array}{c}\text { 2DE, HCT-Ultra ETD } \\
\text { II IT-MS }\end{array}$ & $\begin{array}{l}\text { Peptide ion } \\
\text { score }>30\end{array}$ & 22848560 \\
\hline Rylev M et al. & 2011 [178] & $\begin{array}{c}\text { A. } a \text { JP2 strain } \\
\text { HK1651 }\end{array}$ & 114 & 2DE, MALDI-TOF MS & N/A & 21867783 \\
\hline
\end{tabular}

Ion trap: IT, False positive: FP, False-discovery rate: FDR, Matrix assisted laser desorption ionization: MALDI, Time of flight mass spectrometry: TOF MS, Mass spectrometer: MS. * Maximum identified/quantified proteins were report base on the following rules: (1) Only maximum identified protein number was reported if the experiment was done under different conditions. (2) Total protein numbers were reported if the experiment has replicates. (3) The number of identified and quantified proteins were reported if only regulated protein were reported.

Table 3. Proteomic studies on multi-species biofilms including A. actinomycetemcomitans.

\begin{tabular}{|c|c|c|c|c|c|c|}
\hline Author & $\begin{array}{l}\text { Year } \\
\text { (Ref) }\end{array}$ & Brief Description & $\begin{array}{l}\text { Identified } \\
\text { Proteins * }\end{array}$ & $\begin{array}{c}\text { Proteomic } \\
\text { Application }\end{array}$ & $\begin{array}{l}\text { Peptide } \\
\text { Cutoff }\end{array}$ & PMID \\
\hline Bao et al. & 2018 [169] & $\begin{array}{l}\text { A. } a \text { hns }+10 \text { species } \\
\text { biofilms }\end{array}$ & 3352 & $\begin{array}{c}\text { Orbitrap } \\
\text { Fusion, LFQ }\end{array}$ & $2 \geq$ & 25483866 \\
\hline Bao et al. & 2015 [183] & $\begin{array}{l}\text { 10-species biofilm model } \\
\text { Vs 3D culture }\end{array}$ & 3363 & $\begin{array}{l}\text { Q-Exactive } \\
\text { MS, LFQ }\end{array}$ & $2 \geq$ & 26525412 \\
\hline Bao et al. & 2015 [170] & A. $a+10$ species biofilms ** & 3352 & $\begin{array}{l}\text { Q-Exactive } \\
\text { MS, LFQ }\end{array}$ & $2 \geq$ & 25756960 \\
\hline
\end{tabular}

A.a: A. actinomycetemcomitans, Label free quantification: LFQ, Matrix-assisted laser desorption ionization- time of flight mass spectrometry: MALDI-TOF MS, Two-Dimensional Differential Gel Electrophoresis: 2DE, * Maxium identified/quantified proteins were report base on the following rules: (1) Only maximum identified protein number was reported if the experiment was done under different conditions. (2) Total protein numbers were reported if the experiment has replicates. (3) The number of identified and quantified proteins were reported if only regulated protein were reported. ** 10-species biofilm model (consisting of Campylobacter rectus, Fusobacterium nucleatum, Porphyromonas gingivalis, Prevotella intermedia, Tannerella forsythia, Treponema denticola, Veillonella dispar, Actinomyces oris, Streptococcus anginosous, Streptococcus oralis).

\section{Horizontal Gene Transfer}

A. actinomycetemcomitans strains can be divided into competent and non-competent ones, which refer to their ability to acquire new genes from up-taken extracellular DNA (eDNA) using homologous recombination. Competent strains may have some advantage of being able to uptake eDNA, which could be related to additional means to repair DNA damage, obtain nucleotides and possibly also novel genes [184]. Approximately 30\% of clinical A. actinomycetemcomitans strains are naturally competent [185], leading to greater genetic diversity, whereas noncompetent strains are genetically stable and need to use other mechanisms, such as conjugative plasmids, for horizontal gene transfer (HGT) [186]. It is thought that the ancestral Pasteurellacean was naturally competent and that 
noncompetent lineages lost their ability to take up DNA due to various mutations in the competence gene locus [187]. This may explain the findings that noncompetent strains are more common among some serotype groups, such as serotype $b$ and $c$ [185]. The competence gene locus consists of regulatory sxy, DNA uptake-related com $A B C D E$, pil $A B C D$, comEAFE1, rec2, and transformation-related comM and urpA $[186,188,189]$. Noncompetent strains may contain nonsense mutations, or insertions in one or several of these genes, which makes the strain either unable to uptake eDNA and/or to incorporate it into the genome [186]. In addition to the above described gene locus, the CRISPR-cas system is also closely involved in natural competence, since the loss of CRISPR-cas system is connected to the loss of competence [186]. Thus, non-competent $A$. actinomycetemcomitans strains are more prone to HGT caused by plasmids and phages. However, in the non-competent strains, the maintained CRISPRs contains few spacers that most likely are used for chromosomal gene regulation, since they possess specificity for endogenous genes [186].

The expression on genes of competence locus are regulated by $s x y\left(t f_{0} X\right)$, of which levels in the cell is affected by various environmental factors, such as extracellular calcium ions [190] and the biofilm mode of growth [190]. Moreover, in addition to competence locus and CRISPR-cas system, the development of competence and expression levels of sxy are stimulated by cyclic AMP [191] and affected by the pga gene cluster [190], respectively. The genes in pga cluster are needed in the production of most abundant extracellular polysaccharide, $\mathrm{N}$-acetyl-D-glucosamine, in A. actinomycetemcomitans biofilms.

Naturally competent $A$. actinomycetemcomitans strains recognize related eDNA, which is suitable to be taken up, using uptake signal sequence (USS). The Pasteurellaceae family has two types of USS, Hin and ApI, which contain distinctive consensus sequences of nine base pairs. A. actinomycetemcomitans has Hin type USS, consisting of A. actinomycetemcomitans GTGCGGT consensus sequence followed by AT-rich repeats $[187,191]$. This sequence is most likely recognized by the outer membrane proteins involved in the eDNA uptake. However, the recognizing protein has not yet been identified.

\section{Conclusions}

Aggregatibacter actinomycetemcomitans is a facultative anaerobic Gram-negative bacterium with the capacity to employ many virulence mechanisms closely associated to the pathogenesis of periodontitis. The variety of virulence properties of this bacterium contribute to the pathogenicity of this species, particularly with regard to early and rapidly progressive forms of periodontal disease. A. actinomycetemcomitans can be found in a large proportion of the human population, and due to the large genetic diversity of this species, several different genotypes or phenotypes with various virulence properties have emerged. Without doubt, individuals carrying A. actinomycetemcomitans genotypes with a proven enhanced leukotoxin production have a significantly increased risk to develop disease. More recent studies have identified suitable genes of this species, which can potentially be traced as markers for epidemiological population monitoring and utilization in individual risk assessment programs. Such bacterial virulence markers in periodontal disease may prove to be important tools in future strategies for personalized dentistry.

Author Contributions: Conceptualization, A.J., G.N.B., N.B., J.O., K.B., M.L., R.I., and T.M; Leukotoxin, A.J; Cytolethal distending toxin, G.N.B.; Outer membrane vesicles, M.L. and J.O.; Lipopolysaccharides, cytokine binding and horizontal gene transfer, R.I. and T.M.; Proteomic N.B. and K.B.; Data Curation, A.J., R.I., and J.O.; Writing-Original Draft Preparation, A.J. and G.N.B.; Writing-Review \& Editing, A.J., G.N.B., N.B., J.O., K.B., M.L., R.I., and T.M.

Funding: This work was supported by institutional funds and by funds from the Swedish Research Council (N.B.; 2017-01198), TUA grants from the County Council of Västerbotten, Sweden (A.J.; 7003193), and the Academy of Finland (R.I.; 265609, 303781).

Acknowledgments: We thank the European Network for A. actinomycetemcomitans Research (https://projects.au. $\mathrm{dk} /$ aggregatibacter/) for encouraging us to prepare this review. In addition, we thank Rolf Claesson for the nice photos for Figure 1 and Sotirios Kalfas for excellent artwork in Figure 2.

Conflicts of Interest: The authors declare no conflict of interest. 


\section{References}

1. Henderson, B.; Ward, J.M.; Ready, D. Aggregatibacter (Actinobacillus) actinomycetemcomitans: A triple A* periodontopathogen? Periodontology 2000 2010, 54, 78-105. [CrossRef] [PubMed]

2. Åberg, C.H.; Kelk, P.; Johansson, A. Aggregatibacter actinomycetemcomitans: Virulence of its leukotoxin and association with aggressive periodontitis. Virulence 2015, 6, 188-195. [CrossRef] [PubMed]

3. Fine, D.H.; Patil, A.G.; Velusamy, S.K. Aggregatibacter actinomycetemcomitans (Aa) Under the Radar: Myths and Misunderstandings of Aa and Its Role in Aggressive Periodontitis. Front. Immunol. 2019, $10,728$. [CrossRef] [PubMed]

4. Johansson, A. Aggregatibacter actinomycetemcomitans leukotoxin: A powerful tool with capacity to cause imbalance in the host inflammatory response. Toxins 2011, 3, 242-259. [CrossRef] [PubMed]

5. Vega, B.A.; Belinka, B.A., Jr.; Kachlany, S.C. Aggregatibacter actinomycetemcomitans Leukotoxin (LtxA.; Leukothera((R))): Mechanisms of Action and Therapeutic Applications. Toxins 2019, 11, 489. [CrossRef]

6. DiRienzo, J.M. Breaking the Gingival Epithelial Barrier: Role of the Aggregatibacter actinomycetemcomitans Cytolethal Distending Toxin in Oral Infectious Disease. Cells 2014, 3, 476-499. [CrossRef]

7. Fujise, O.; Wang, Y.; Chen, W.; Chen, C. Adherence of Aggregatibacter actinomycetemcomitans via serotype-specific polysaccharide antigens in lipopolysaccharides. Oral Microbiol. Immunol. 2008, 23, 226-233. [CrossRef]

8. Oscarsson, J.; Claesson, R.; Lindholm, M.; Höglund Åberg, C.; Johansson, A. Tools of Aggregatibacter actinomycetemcomitans to Evade the Host Response. J. Clin. Med. 2019, 8, 1079. [CrossRef]

9. Thay, B.; Damm, A.; Kufer, T.A.; Wai, S.N.; Oscarsson, J. Aggregatibacter actinomycetemcomitans outer membrane vesicles are internalized in human host cells and trigger NOD1- and NOD2-dependent NF-kappaB activation. Infect. Immun. 2014, 82, 4034-4046. [CrossRef]

10. Kittichotirat, W.; Bumgarner, R.E.; Chen, C. Evolutionary Divergence of Aggregatibacter actinomycetemcomitans. J. Dent. Res. 2016, 95, 94-101. [CrossRef]

11. Bao, K.; Bostanci, N.; Thurnheer, T.; Grossmann, J.; Wolski, W.E.; Thay, B.; Belibasakis, G.N.; Oscarsson, J. Aggregatibacter actinomycetemcomitans $\mathrm{H}-\mathrm{NS}$ promotes biofilm formation and alters protein dynamics of other species within a polymicrobial oral biofilm. NPJ Biofilms Microbiomes 2018, 4, 12. [CrossRef] [PubMed]

12. Belibasakis, G.N.; Bostanci, N.; Marsh, P.D.; Zaura, E. Applications of the oral microbiome in personalized dentistry. Arch. Oral Biol. 2019, 104, 7-12. [CrossRef] [PubMed]

13. Claesson, R.; Johansson, A.; Belibasakis, G.; Hanstrom, L.; Kalfas, S. Release and activation of matrix metalloproteinase 8 from human neutrophils triggered by the leukotoxin of Actinobacillus actinomycetemcomitans. J. Periodontal Res. 2002, 37, 353-359. [CrossRef] [PubMed]

14. Johansson, A.; Claesson, R.; Hanstrom, L.; Sandstrom, G.; Kalfas, S. Polymorphonuclear leukocyte degranulation induced by leukotoxin from Actinobacillus actinomycetemcomitans. J. Periodontal Res. 2000, 35, 85-92. [CrossRef]

15. Hirschfeld, J.; Roberts, H.M.; Chapple, I.L.; Parcina, M.; Jepsen, S.; Johansson, A.; Claesson, R. Effects of Aggregatibacter actinomycetemcomitans leukotoxin on neutrophil migration and extracellular trap formation. J. Oral Microbiol. 2016, 8, 33070. [CrossRef]

16. Lopes, J.P.; Stylianou, M.; Backman, E.; Holmberg, S.; Jass, J.; Claesson, R.; Urban, C.F. Evasion of Immune Surveillance in Low Oxygen Environments Enhances Candida albicans Virulence. mBio 2018, 9. [CrossRef]

17. Konig, M.F.; Abusleme, L.; Reinholdt, J.; Palmer, R.J.; Teles, R.P.; Sampson, K.; Rosen, A.; Nigrovic, P.A.; Sokolove, J.; Giles, J.T.; et al. Aggregatibacter actinomycetemcomitans-induced hypercitrullination links periodontal infection to autoimmunity in rheumatoid arthritis. Sci. Transl. Med. 2016, 8, 369ra176. [CrossRef]

18. DiFranco, K.M.; Gupta, A.; Galusha, L.E.; Perez, J.; Nguyen, T.V.; Fineza, C.D.; Kachlany, S.C. Leukotoxin (Leukothera(R)) targets active leukocyte function antigen-1 (LFA-1) protein and triggers a lysosomal mediated cell death pathway. J. Biol. Chem. 2012, 287, 17618-17627. [CrossRef]

19. Kelk, P.; Abd, H.; Claesson, R.; Sandstrom, G.; Sjostedt, A.; Johansson, A. Cellular and molecular response of human macrophages exposed to Aggregatibacter actinomycetemcomitans leukotoxin. Cell Death Dis. 2011, 2, e126. [CrossRef]

20. Haubek, D.; Johansson, A. Pathogenicity of the highly leukotoxic JP2 clone of Aggregatibacter actinomycetemcomitans and its geographic dissemination and role in aggressive periodontitis. J. Oral Microbiol. 2014, 6. [CrossRef] 
21. Kononen, E.; Gursoy, M.; Gursoy, U.K. Periodontitis: A Multifaceted Disease of Tooth-Supporting Tissues. J. Clin. Med. 2019, 8, 1135. [CrossRef]

22. Lally, E.T.; Golub, E.E.; Kieba, I.R. Identification and immunological characterization of the domain of Actinobacillus actinomycetemcomitans leukotoxin that determines its specificity for human target cells. J. Biol. Chem. 1994, 269, 31289-31295.

23. Lally, E.T.; Kieba, I.R.; Sato, A.; Green, C.L.; Rosenbloom, J.; Korostoff, J.; Wang, J.F.; Shenker, B.J.; Ortlepp, S.; Robinson, M.K.; et al. RTX toxins recognize a beta2 integrin on the surface of human target cells. J. Biol. Chem. 1997, 272, 30463-30469. [CrossRef]

24. Dileepan, T.; Kachlany, S.C.; Balashova, N.V.; Patel, J.; Maheswaran, S.K. Human CD18 is the functional receptor for Aggregatibacter actinomycetemcomitans leukotoxin. Infect. Immun. 2007, 75, 4851-4856. [CrossRef]

25. Kieba, I.R.; Fong, K.P.; Tang, H.Y.; Hoffman, K.E.; Speicher, D.W.; Klickstein, L.B.; Lally, E.T. Aggregatibacter actinomycetemcomitans leukotoxin requires beta-sheets 1 and 2 of the human CD11a beta-propeller for cytotoxicity. Cell. Microbiol. 2007, 9, 2689-2699. [CrossRef]

26. Ristow, L.C.; Tran, V.; Schwartz, K.J.; Pankratz, L.; Mehle, A.; Sauer, J.D.; Welch, R.A. The Extracellular Domain of the beta2 Integrin beta Subunit (CD18) Is Sufficient for Escherichia coli Hemolysin and Aggregatibacter actinomycetemcomitans Leukotoxin Cytotoxic Activity. mBio 2019, 10. [CrossRef]

27. Lally, E.T.; Hill, R.B.; Kieba, I.R.; Korostoff, J. The interaction between RTX toxins and target cells. Trends Microbiol. 1999, 7, 356-361. [CrossRef]

28. Kittichotirat, W.; Bumgarner, R.E.; Asikainen, S.; Chen, C. Identification of the pangenome and its components in 14 distinct Aggregatibacter actinomycetemcomitans strains by comparative genomic analysis. PLoS ONE 2011, 6, e22420. [CrossRef]

29. Haubek, D. The highly leukotoxic JP2 clone of Aggregatibacter actinomycetemcomitans: Evolutionary aspects, epidemiology and etiological role in aggressive periodontitis. APMIS Suppl. 2010, 1-53. [CrossRef]

30. Zambon, J.J. Actinobacillus actinomycetemcomitans in adult periodontitis. J. Periodontol. 1994, 65, 892-893. [CrossRef]

31. Haubek, D.; Ennibi, O.K.; Poulsen, K.; Vaeth, M.; Poulsen, S.; Kilian, M. Risk of aggressive periodontitis in adolescent carriers of the JP2 clone of Aggregatibacter (Actinobacillus) actinomycetemcomitans in Morocco: A prospective longitudinal cohort study. Lancet 2008, 371, 237-242. [CrossRef]

32. Höglund Åberg, C.; Kwamin, F.; Claesson, R.; Dahlen, G.; Johansson, A.; Haubek, D. Progression of attachment loss is strongly associated with presence of the JP2 genotype of Aggregatibacter actinomycetemcomitans: A prospective cohort study of a young adolescent population. J. Clin. Periodontol. 2014, 41, 232-241. [CrossRef]

33. Brogan, J.M.; Lally, E.T.; Poulsen, K.; Kilian, M.; Demuth, D.R. Regulation of Actinobacillus actinomycetemcomitans leukotoxin expression: Analysis of the promoter regions of leukotoxic and minimally leukotoxic strains. Infect. Immun. 1994, 62, 501-508.

34. Tsai, C.C.; Ho, Y.P.; Chou, Y.S.; Ho, K.Y.; Wu, Y.M.; Lin, Y.C. Aggregatibacter (Actinobacillus) actimycetemcomitans leukotoxin and human periodontitis-A historic review with emphasis on JP2. Kaohsiung J. Med. Sci. 2018, 34, 186-193. [CrossRef]

35. Zambon, J.J.; Haraszthy, V.I.; Hariharan, G.; Lally, E.T.; Demuth, D.R. The Microbiology of Early-Onset Periodontitis: Association of Highly Toxic Actinobacillus actinomycetemcomitans Strains with Localized Juvenile Periodontitis. J. Periodontol. 1996, 67 (Suppl. 3S), 282-290. [CrossRef]

36. Aberg, C.H.; Kwamin, F.; Claesson, R.; Johansson, A.; Haubek, D. Presence of JP2 and Non-JP2 Genotypes of Aggregatibacter actinomycetemcomitans and attachment loss in adolescents in Ghana. J. Periodontol. 2012, 83, 1520-1528. [CrossRef]

37. Claesson, R.; Lagervall, M.; Hoglund-Aberg, C.; Johansson, A.; Haubek, D. Detection of the highly leucotoxic JP2 clone of Aggregatibacter actinomycetemcomitans in members of a Caucasian family living in Sweden. J. Clin. Periodontol. 2011, 38, 115-121. [CrossRef]

38. Claesson, R.; Höglund-Åberg, C.; Haubek, D.; Johansson, A. Age-related prevalence and characteristics of Aggregatibacter actinomycetemcomitans in periodontitis patients living in Sweden. J. Oral Microbiol. 2017, 9, 1334504. [CrossRef]

39. He, T.; Nishihara, T.; Demuth, D.R.; Ishikawa, I. A novel insertion sequence increases the expression of leukotoxicity in Actinobacillus actinomycetemcomitans clinical isolates. J. Periodontol. 1999, 70, 1261-1268. [CrossRef] 
40. Claesson, R.; Gudmundson, J.; Åberg, C.H.; Haubek, D.; Johansson, A. Detection of a 640-bp deletion in the Aggregatibacter actinomycetemcomitans leukotoxin promoter region in isolates from an adolescent of Ethiopian origin. J. Oral Microbiol. 2015, 7, 26974. [CrossRef]

41. Höglund Åberg, C.; Haubek, D.; Kwamin, F.; Johansson, A.; Claesson, R. Leukotoxic activity of Aggregatibacter actinomycetemcomitans and periodontal attachment loss. PLoS ONE 2014, 9, e104095. [CrossRef] [PubMed]

42. Johansson, A.; Claesson, R.; Höglund Åberg, C.; Haubek, D.; Lindholm, M.; Jasim, S.; Oscarsson, J. Genetic Profiling of Aggregatibacter actinomycetemcomitans Serotype B Isolated from Periodontitis Patients Living in Sweden. Pathogenes 2019, 8, 153. [CrossRef] [PubMed]

43. Johansson, A.; Claesson, R.; Höglund Åberg, C.; Haubek, D.; Oscarsson, J. The cagE gene sequence as a diagnostic marker to identify JP2 and non-JP2 highly leukotoxic Aggregatibacter actinomycetemcomitans serotype b strains. J. Periodontal Res. 2017, 52, 903-912. [CrossRef] [PubMed]

44. Gomez-Banuelos, E.; Mukherjee, A.; Darrah, E.; Andrade, F. Rheumatoid Arthritis-Associated Mechanisms of Porphyromonas gingivalis and Aggregatibacter actinomycetemcomitans. J. Clin. Med. 2019, 8, 1309. [CrossRef]

45. Skals, M.; Greve, A.S.; Fagerberg, S.K.; Johnsen, N.; Christensen, M.G.; Praetorius, H.A. P2X1 receptor blockers reduce the number of circulating thrombocytes and the overall survival of urosepsis with haemolysin-producing Escherichia coli. Purinergic Signal. 2019, 15, 265-276. [CrossRef] [PubMed]

46. Kachlany, S.C. Aggregatibacter actinomycetemcomitans leukotoxin: From threat to therapy. J. Dent. Res. 2010, 89, 561-570. [CrossRef]

47. Linhartova, I.; Bumba, L.; Masin, J.; Basler, M.; Osicka, R.; Kamanova, J.; Prochazkova, K.; Adkins, I.; Hejnova-Holubova, J.; Sadilkova, L.; et al. RTX proteins: A highly diverse family secreted by a common mechanism. FEMS Microbiol. Rev. 2010, 34, 1076-1112. [CrossRef]

48. Harding, C.M.; Pulido, M.R.; Di Venanzio, G.; Kinsella, R.L.; Webb, A.I.; Scott, N.E.; Pachon, J.; Feldman, M.F. Pathogenic Acinetobacter species have a functional type I secretion system and contact-dependent inhibition systems. J. Biol. Chem. 2017, 292, 9075-9087. [CrossRef]

49. Crosby, J.A.; Kachlany, S.C. TdeA, a TolC-like protein required for toxin and drug export in Aggregatibacter (Actinobacillus) actinomycetemcomitans. Gene 2007, 388, 83-92. [CrossRef]

50. Gallant, C.V.; Sedic, M.; Chicoine, E.A.; Ruiz, T.; Mintz, K.P. Membrane morphology and leukotoxin secretion are associated with a novel membrane protein of Aggregatibacter actinomycetemcomitans. J. Bacteriol. 2008, 190, 5972-5980. [CrossRef]

51. Berthold, P.; Forti, D.; Kieba, I.R.; Rosenbloom, J.; Taichman, N.S.; Lally, E.T. Electron immunocytochemical localization of Actinobacillus actinomycetemcomitans leukotoxin. Oral Microbiol. Immunol. 1992, 7, $24-27$. [CrossRef] [PubMed]

52. Kato, S.; Kowashi, Y.; Demuth, D.R. Outer membrane-like vesicles secreted by Actinobacillus actinomycetemcomitans are enriched in leukotoxin. Microb. Pathog. 2002, 32, 1-13. [CrossRef] [PubMed]

53. Ohta, H.; Kato, K.; Kokeguchi, S.; Hara, H.; Fukui, K.; Murayama, Y. Nuclease-sensitive binding of an Actinobacillus actinomycetemcomitans leukotoxin to the bacterial cell surface. Infect. Immun. 1991, 59, 4599-4605. [PubMed]

54. Ohta, H.; Hara, H.; Fukui, K.; Kurihara, H.; Murayama, Y.; Kato, K. Association of Actinobacillus actinomycetemcomitans leukotoxin with nucleic acids on the bacterial cell surface. Infect. Immun. 1993, $61,4878-4884$.

55. Johansson, A.; Hanstrom, L.; Kalfas, S. Inhibition of Actinobacillus actinomycetemcomitans leukotoxicity by bacteria from the subgingival flora. Oral Microbiol. Immunol. 2000, 15, 218-225. [CrossRef]

56. Johansson, A.; Claesson, R.; Hanstrom, L.; Kalfas, S. Serum-mediated release of leukotoxin from the cell surface of the periodontal pathogen Actinobacillus actinomycetemcomitans. Eur. J. Oral Sci. 2003, 111, 209-215. [CrossRef]

57. Balashova, N.V.; Diaz, R.; Balashov, S.V.; Crosby, J.A.; Kachlany, S.C. Regulation of Aggregatibacter (Actinobacillus) actinomycetemcomitans leukotoxin secretion by iron. J. Bacteriol. 2006, 188, 8658-8661. [CrossRef]

58. Reinholdt, J.; Poulsen, K.; Brinkmann, C.R.; Hoffmann, S.V.; Stapulionis, R.; Enghild, J.J.; Jensen, U.B.; Boesen, T.; Vorup-Jensen, T. Monodisperse and LPS-free Aggregatibacter actinomycetemcomitans leukotoxin: Interactions with human beta2 integrins and erythrocytes. Biochim. Biophys. Acta 2013, 1834, 546-558. [CrossRef] 
59. Brage, M.; Holmlund, A.; Johansson, A. Humoral immune response to Aggregatibacter actinomycetemcomitans leukotoxin. J. Periodontal Res. 2011, 46, 170-175. [CrossRef]

60. Johansson, A.; Buhlin, K.; Sorsa, T.; Pussinen, P.J. Systemic Aggregatibacter actinomycetemcomitans Leukotoxin-Neutralizing Antibodies in Periodontitis. J. Periodontol. 2017, 88, 122-129. [CrossRef]

61. Johansson, A.; Claesson, R.; Belibasakis, G.; Makoveichuk, E.; Hanstrom, L.; Olivecrona, G.; Sandstrom, G.; Kalfas, S. Protease inhibitors, the responsible components for the serum-dependent enhancement of Actinobacillus actinomycetemcomitans leukotoxicity. Eur. J. Oral Sci. 2001, 109, 335-341. [CrossRef] [PubMed]

62. Balashova, N.V.; Park, D.H.; Patel, J.K.; Figurski, D.H.; Kachlany, S.C. Interaction between leukotoxin and $\mathrm{Cu}, \mathrm{Zn}$ superoxide dismutase in Aggregatibacter actinomycetemcomitans. Infect. Immun. 2007, 75, 4490-4497. [CrossRef] [PubMed]

63. McArthur, W.P.; Tsai, C.C.; Baehni, P.C.; Genco, R.J.; Taichman, N.S. Leukotoxic effects of Actinobacillus actinomycetemcomitans. Modulation by serum components. J. Periodontal Res. 1981, 16, 159-170. [CrossRef] [PubMed]

64. Johansson, A.; Claesson, R.; Belibasakis, G.; Makoveichuk, E.; Hanstrom, L.; Olivecrona, G.; Kalfas, S. Lack of lipoprotein-dependent effects on the cytotoxic interactions of Actinobacillus actinomycetemcomitans leukotoxin with human neutrophils. APMIS 2002, 110, 857-862. [CrossRef]

65. Hritz, M.; Fisher, E.; Demuth, D.R. Differential regulation of the leukotoxin operon in highly leukotoxic and minimally leukotoxic strains of Actinobacillus actinomycetemcomitans. Infect. Immun. 1996, 64, 2724-2729.

66. Tsai, C.C.; McArthur, W.P.; Baehni, P.C.; Hammond, B.F.; Taichman, N.S. Extraction and partial characterization of a leukotoxin from a plaque-derived Gram-negative microorganism. Infect. Immun. 1979, 25, 427-439.

67. Zambon, J.J.; DeLuca, C.; Slots, J.; Genco, R.J. Studies of leukotoxin from Actinobacillus actinomycetemcomitans using the promyelocytic HL-60 cell line. Infect. Immun. 1983, 40, 205-212.

68. Sampathkumar, V.; Velusamy, S.K.; Godboley, D.; Fine, D.H. Increased leukotoxin production: Characterization of 100 base pairs within the 530 base pair leukotoxin promoter region of Aggregatibacter actinomycetemcomitans. Sci. Rep. 2017, 7, 1887. [CrossRef]

69. Kelk, P.; Claesson, R.; Chen, C.; Sjostedt, A.; Johansson, A. IL-1beta secretion induced by Aggregatibacter (Actinobacillus) actinomycetemcomitans is mainly caused by the leukotoxin. Int. J. Med. Microbiol. IJMM 2008, 298, 529-541. [CrossRef]

70. Umeda, J.E.; Longo, P.L.; Simionato, M.R.; Mayer, M.P. Differential transcription of virulence genes in Aggregatibacter actinomycetemcomitans serotypes. J. Oral Microbiol. 2013, 5. [CrossRef]

71. Lara-Tejero, M.; Galan, J.E. A bacterial toxin that controls cell cycle progression as a deoxyribonuclease I-like protein. Science 2000, 290, 354-357. [CrossRef] [PubMed]

72. Boesze-Battaglia, K.; Besack, D.; McKay, T.; Zekavat, A.; Otis, L.; Jordan-Sciutto, K.; Shenker, B.J. Cholesterol-rich membrane microdomains mediate cell cycle arrest induced by Actinobacillus actinomycetemcomitans cytolethal-distending toxin. Cell Microbiol. 2006, 8, 823-836. [CrossRef] [PubMed]

73. Boesze-Battaglia, K.; Alexander, D.; Dlakic, M.; Shenker, B.J. A Journey of Cytolethal Distending Toxins through Cell Membranes. Front. Cell. Infect. Microbiol. 2016, 6, 81. [CrossRef] [PubMed]

74. Fais, T.; Delmas, J.; Serres, A.; Bonnet, R.; Dalmasso, G. Impact of CDT Toxin on Human Diseases. Toxins 2016, 8, 220. [CrossRef] [PubMed]

75. Belibasakis, G.; Johansson, A.; Wang, Y.; Claesson, R.; Chen, C.; Asikainen, S.; Kalfas, S. Inhibited proliferation of human periodontal ligament cells and gingival fibroblasts by Actinobacillus actinomycetemcomitans: Involvement of the cytolethal distending toxin. Eur. J. Oral Sci. 2002, 110, 366-373. [CrossRef]

76. Belibasakis, G.N.; Mattsson, A.; Wang, Y.; Chen, C.; Johansson, A. Cell cycle arrest of human gingival fibroblasts and periodontal ligament cells by Actinobacillus actinomycetemcomitans: Involvement of the cytolethal distending toxin. APMIS 2004, 112, 674-685. [CrossRef]

77. Kang, P.; Korostoff, J.; Volgina, A.; Grzesik, W.; DiRienzo, J.M. Differential effect of the cytolethal distending toxin of Actinobacillus actinomycetemcomitans on co-cultures of human oral cells. J. Med. Microbiol. 2005, 54, 785-794. [CrossRef]

78. Alaoui-El-Azher, M.; Mans, J.J.; Baker, H.V.; Chen, C.; Progulske-Fox, A.; Lamont, R.J.; Handfield, M. Role of the ATM-checkpoint kinase 2 pathway in CDT-mediated apoptosis of gingival epithelial cells. PLoS ONE 2010, 5, e11714. [CrossRef]

79. Damek-Poprawa, M.; Haris, M.; Volgina, A.; Korostoff, J.; DiRienzo, J.M. Cytolethal distending toxin damages the oral epithelium of gingival explants. J. Dent. Res. 2011, 90, 874-879. [CrossRef] 
80. Kanno, F.; Korostoff, J.; Volgina, A.; DiRienzo, J.M. Resistance of human periodontal ligament fibroblasts to the cytolethal distending toxin of Actinobacillus actinomycetemcomitans. J. Periodontol. 2005, 76, 1189-1201. [CrossRef]

81. Damek-Poprawa, M.; Korostoff, J.; Gill, R.; DiRienzo, J.M. Cell junction remodeling in gingival tissue exposed to a microbial toxin. J. Dent. Res. 2013, 92, 518-523. [CrossRef] [PubMed]

82. Ohara, M.; Miyauchi, M.; Tsuruda, K.; Takata, T.; Sugai, M. Topical application of Aggregatibacter actinomycetemcomitans cytolethal distending toxin induces cell cycle arrest in the rat gingival epithelium in vivo. J. Periodontal Res. 2011, 46, 389-395. [CrossRef] [PubMed]

83. Shenker, B.J.; McKay, T.; Datar, S.; Miller, M.; Chowhan, R.; Demuth, D. Actinobacillus actinomycetemcomitans immunosuppressive protein is a member of the family of cytolethal distending toxins capable of causing a G2 arrest in human T cells. J. Immunol. 1999, 162, 4773-4780. [PubMed]

84. Sato, T.; Koseki, T.; Yamato, K.; Saiki, K.; Konishi, K.; Yoshikawa, M.; Ishikawa, I.; Nishihara, T. p53-independent expression of p21(CIP1/WAF1) in plasmacytic cells during $\mathrm{G}(2)$ cell cycle arrest induced by Actinobacillus actinomycetemcomitans cytolethal distending toxin. Infect. Immun. 2002, 70, 528-534. [CrossRef] [PubMed]

85. Akifusa, S.; Poole, S.; Lewthwaite, J.; Henderson, B.; Nair, S.P. Recombinant Actinobacillus actinomycetemcomitans cytolethal distending toxin proteins are required to interact to inhibit human cell cycle progression and to stimulate human leukocyte cytokine synthesis. Infect. Immun. 2001, 69, 5925-5930. [CrossRef] [PubMed]

86. Belibasakis, G.N.; Bostanci, N. Inflammatory and bone remodeling responses to the cytolethal distending toxins. Cells 2014, 3, 236-246. [CrossRef]

87. Oscarsson, J.; Karched, M.; Thay, B.; Chen, C.; Asikainen, S. Proinflammatory effect in whole blood by free soluble bacterial components released from planktonic and biofilm cells. BMC Microbiol. 2008, 8, 206. [CrossRef]

88. Belibasakis, G.N.; Johansson, A. Aggregatibacter actinomycetemcomitans targets NLRP3 and NLRP6 inflammasome expression in human mononuclear leukocytes. Cytokine 2012, 59, 124-130. [CrossRef]

89. Belibasakis, G.N.; Bostanci, N. The RANKL-OPG system in clinical periodontology. J. Clin. Periodontol. 2012, 39, 239-248. [CrossRef]

90. Belibasakis, G.N.; Johansson, A.; Wang, Y.; Chen, C.; Kalfas, S.; Lerner, U.H. The cytolethal distending toxin induces receptor activator of NF-kappaB ligand expression in human gingival fibroblasts and periodontal ligament cells. Infect. Immun. 2005, 73, 342-351. [CrossRef]

91. Belibasakis, G.N.; Johansson, A.; Wang, Y.; Chen, C.; Lagergård, T.; Kalfas, S.; Lerner, U.H. Cytokine responses of human gingival fibroblasts to Actinobacillus actinomycetemcomitans cytolethal distending toxin. Cytokine 2005, 30, 56-63. [CrossRef] [PubMed]

92. Belibasakis, G.N.; Brage, M.; Lagergard, T.; Johansson, A. Cytolethal distending toxin upregulates RANKL expression in Jurkat T-cells. APMIS 2008, 116, 499-506. [CrossRef] [PubMed]

93. Kawamoto, D.; Ando-Suguimoto, E.S.; Bueno-Silva, B.; DiRienzo, J.M.; Mayer, M.P. Alteration of Homeostasis in Pre-osteoclasts Induced by Aggregatibacter actinomycetemcomitans CDT. Front. Cell. Infect. Microbiol. 2016, 6, 33. [CrossRef] [PubMed]

94. Kaplan, J.B.; Perry, M.B.; MacLean, L.L.; Furgang, D.; Wilson, M.E.; Fine, D.H. Structural and genetic analyses of $\mathrm{O}$ polysaccharide from Actinobacillus actinomycetemcomitans serotype f. Infect. Immun. 2001, 69, 5375-5384. [CrossRef]

95. Perry, M.B.; MacLean, L.M.; Brisson, J.R.; Wilson, M.E. Structures of the antigenic O-polysaccharides of lipopolysaccharides produced by Actinobacillus actinomycetemcomitans serotypes a, c, d and e. Eur. J. Biochem. 1996, 242, 682-688. [CrossRef]

96. Perry, M.B.; MacLean, L.L.; Gmur, R.; Wilson, M.E. Characterization of the O-polysaccharide structure of lipopolysaccharide from Actinobacillus actinomycetemcomitans serotype b. Infect. Immun. 1996, 64, 1215-1219.

97. Masoud, H.; Weintraub, S.T.; Wang, R.; Cotter, R.; Holt, S.C. Investigation of the structure of lipid A from Actinobacillus actinomycetemcomitans strain $\mathrm{Y} 4$ and human clinical isolate PO 1021-7. Eur. J. Biochem. 1991, 200, 775-781. [CrossRef]

98. Suzuki, N.; Nakano, Y.; Yoshida, Y.; Ikeda, D.; Koga, T. Identification of Actinobacillus actinomycetemcomitans serotypes by multiplex PCR. J. Clin. Microbiol. 2001, 39, 2002-2005. [CrossRef] 
99. Brondz, I.; Olsen, I. Chemical differences in lipopolysaccharides from Actinobacillus (Haemophilus) actinomycetemcomitans and Haemophilus aphrophilus: Clues to differences in periodontopathogenic potential and taxonomic distinction. Infect. Immun. 1989, 57, 3106-3109.

100. Brondz, I.; Olsen, I. Determination of acids in whole lipopolysaccharide and in free lipid A from Actinobacillus actinomycetemcomitans and Haemophilus aphrophilus. J. Chromatogr. 1984, 308, 19-29. [CrossRef]

101. Bryn, K.; Jantzen, E. Analysis of lipopolysaccharides by methanolysis, trifluoroacetylation, and gas chromatography on a fused-silica capillary column. J. Chromatogr. 1982, 240, 405-413. [CrossRef]

102. Kiley, P.; Holt, S.C. Characterization of the lipopolysaccharide from Actinobacillus actinomycetemcomitans $\mathrm{Y} 4$ and N27. Infect. Immun. 1980, 30, 862-873. [PubMed]

103. Schneider, B.; Weigel, W.; Sztukowska, M.; Demuth, D.R. Identification and functional characterization of type II toxin/antitoxin systems in Aggregatibacter actinomycetemcomitans. Mol. Oral Microbiol. 2018, 33, 224-233. [CrossRef] [PubMed]

104. Sreenivasan, P.K.; Meyer, D.H.; Fives-Taylor, P.M. Factors influencing the growth and viability of Actinobacillus actinomycetemcomitans. Oral Microbiol. Immunol. 1993, 8, 361-369. [CrossRef] [PubMed]

105. Brondz, I.; Olsen, I. Differentiation between Actinobacillus actinomycetemcomitans and Haemophilus aphrophilus based on carbohydrates in lipopolysaccharide. J. Chromatogr. 1984, 310, 261-272. [CrossRef]

106. Brondz, I.; Olsen, I. Multivariate analyses of carbohydrate data from lipopolysaccharides of Actinobacillus (Haemophilus) actinomycetemcomitans, Haemophilus aphrophilus, and Haemophilus paraphrophilus. Int. J. Syst. Bacteriol. 1990, 40, 405-408. [CrossRef]

107. Patil, C.; Rossa, C., Jr.; Kirkwood, K.L. Actinobacillus actinomycetemcomitans lipopolysaccharide induces interleukin-6 expression through multiple mitogen-activated protein kinase pathways in periodontal ligament fibroblasts. Oral Microbiol. Immunol. 2006, 21, 392-398. [CrossRef]

108. Rogers, J.E.; Li, F.; Coatney, D.D.; Rossa, C.; Bronson, P.; Krieder, J.M.; Giannobile, W.V.; Kirkwood, K.L. Actinobacillus actinomycetemcomitans lipopolysaccharide-mediated experimental bone loss model for aggressive periodontitis. J. Periodontol. 2007, 78, 550-558. [CrossRef]

109. Morishita, M.; Ariyoshi, W.; Okinaga, T.; Usui, M.; Nakashima, K.; Nishihara, T. A. actinomycetemcomitans LPS enhances foam cell formation induced by LDL. J. Dent. Res. 2013, 92, 241-246. [CrossRef]

110. Park, O.J.; Cho, M.K.; Yun, C.H.; Han, S.H. Lipopolysaccharide of Aggregatibacter actinomycetemcomitans induces the expression of chemokines MCP-1, MIP-1alpha, and IP-10 via similar but distinct signaling pathways in murine macrophages. Immunobiology 2015, 220, 1067-1074. [CrossRef]

111. Valerio, M.S.; Herbert, B.A.; Basilakos, D.S.; Browne, C.; Yu, H.; Kirkwood, K.L. Critical role of MKP-1 in lipopolysaccharide-induced osteoclast formation through CXCL1 and CXCL2. Cytokine 2015, 71, 71-80. [CrossRef] [PubMed]

112. Tao, L.; Reese, T.A. Making Mouse Models That Reflect Human Immune Responses. Trends Immunol. 2017, 38, 181-193. [CrossRef] [PubMed]

113. Suga, T.; Mitani, A.; Mogi, M.; Kikuchi, T.; Fujimura, T.; Takeda, H.; Hishikawa, T.; Yamamoto, G.; Hayashi, J.; Ishihara, Y.; et al. Aggregatibacter actinomycetemcomitans lipopolysaccharide stimulated epithelial cells produce interleukin-15 that regulates T cell activation. Arch. Oral Biol. 2013, 58, 1541-1548. [CrossRef]

114. Takahashi, N.; Kobayashi, M.; Takaki, T.; Takano, K.; Miyata, M.; Okamatsu, Y.; Hasegawa, K.; Nishihara, T.; Yamamoto, M. Actinobacillus actinomycetemcomitans lipopolysaccharide stimulates collagen phagocytosis by human gingival fibroblasts. Oral Microbiol. Immunol. 2008, 23, 259-264. [CrossRef]

115. Xiao, Y.; Bunn, C.L.; Bartold, P.M. Effect of lipopolysaccharide from periodontal pathogens on the production of tissue plasminogen activator and plasminogen activator inhibitor 2 by human gingival fibroblasts. J. Periodontal Res. 2001, 36, 25-31. [CrossRef] [PubMed]

116. Naqvi, A.R.; Fordham, J.B.; Khan, A.; Nares, S. MicroRNAs responsive to Aggregatibacter actinomycetemcomitans and Porphyromonas gingivalis LPS modulate expression of genes regulating innate immunity in human macrophages. Innate Immun. 2014, 20, 540-551. [CrossRef] [PubMed]

117. Taganov, K.D.; Boldin, M.P.; Chang, K.J.; Baltimore, D. NF-kappaB-dependent induction of microRNA miR-146, an inhibitor targeted to signaling proteins of innate immune responses. Proc. Natl. Acad. Sci. USA 2006, 103, 12481-12486. [CrossRef]

118. Gocek, E.; Wang, X.; Liu, X.; Liu, C.G.; Studzinski, G.P. MicroRNA-32 upregulation by 1,25-dihydroxyvitamin D3 in human myeloid leukemia cells leads to Bim targeting and inhibition of AraC-induced apoptosis. Cancer Res. 2011, 71, 6230-6239. [CrossRef] 
119. Sosroseno, W.; Bird, P.S.; Seymour, G.J. Nitric oxide production by a human osteoblast cell line stimulated with Aggregatibacter actinomycetemcomitans lipopolysaccharide. Oral Microbiol. Immunol. 2009, 24, 50-55. [CrossRef]

120. Ralston, S.H.; Grabowski, P.S. Mechanisms of cytokine induced bone resorption: Role of nitric oxide, cyclic guanosine monophosphate, and prostaglandins. Bone 1996, 19, 29-33. [CrossRef]

121. Pollanen, M.T.; Salonen, J.I.; Grenier, D.; Uitto, V.J. Epithelial cell response to challenge of bacterial lipoteichoic acids and lipopolysaccharides in vitro. J. Med. Microbiol. 2000, 49, 245-252. [CrossRef] [PubMed]

122. Ohguchi, Y.; Ishihara, Y.; Ohguchi, M.; Koide, M.; Shirozu, N.; Naganawa, T.; Nishihara, T.; Noguchi, T. Capsular polysaccharide from Actinobacillus actinomycetemcomitans inhibits IL-6 and IL-8 production in human gingival fibroblast. J. Periodontal Res. 2003, 38, 191-197. [CrossRef] [PubMed]

123. Kikuchi, T.; Hahn, C.L.; Tanaka, S.; Barbour, S.E.; Schenkein, H.A.; Tew, J.G. Dendritic cells stimulated with Actinobacillus actinomycetemcomitans elicit rapid gamma interferon responses by natural killer cells. Infect. Immun. 2004, 72, 5089-5096. [CrossRef] [PubMed]

124. Diaz-Zuniga, J.; Yanez, J.P.; Alvarez, C.; Melgar-Rodriguez, S.; Hernandez, M.; Sanz, M.; Vernal, R. Serotype-dependent response of human dendritic cells stimulated with Aggregatibacter actinomycetemcomitans. J. Clin. Periodontol. 2014, 41, 242-251. [CrossRef] [PubMed]

125. Aida, Y.; Kukita, T.; Takada, H.; Maeda, K.; Pabst, M.J. Lipopolysaccharides from periodontal pathogens prime neutrophils for enhanced respiratory burst: Differential effect of a synthetic lipid a precursor IVA (LA-14-PP). J. Periodontal Res. 1995, 30, 116-123. [CrossRef]

126. Yoshimura, A.; Hara, Y.; Kaneko, T.; Kato, I. Secretion of IL-1 beta, TNF-alpha, IL-8 and IL-1ra by human polymorphonuclear leukocytes in response to lipopolysaccharides from periodontopathic bacteria. J. Periodontal Res. 1997, 32, 279-286. [CrossRef]

127. Schytte Blix, I.J.; Helgeland, K.; Hvattum, E.; Lyberg, T. Lipopolysaccharide from Actinobacillus actinomycetemcomitans stimulates production of interleukin-1beta, tumor necrosis factor-alpha, interleukin-6 and interleukin-1 receptor antagonist in human whole blood. J. Periodontal Res. 1999, 34, 34-40. [CrossRef]

128. Blix, I.J.; Helgeland, K.; Kahler, H.; Lyberg, T. LPS from Actinobacillus actinomycetemcomitans and the expression of beta2 integrins and L-selectin in an ex vivo human whole blood system. Eur. J. Oral Sci. 1999, 107, 14-20. [CrossRef]

129. Grenier, D.; Leduc, A.; Mayrand, D. Interaction between Actinobacillus actinomycetemcomitans lipopolysaccharides and human hemoglobin. FEMS Microbiol. Lett. 1997, 151, 77-81. [CrossRef]

130. Ahlstrand, T.; Kovesjoki, L.; Maula, T.; Oscarsson, J.; Ihalin, R. Aggregatibacter actinomycetemcomitans LPS binds human interleukin-8. J. Oral Microbiol. 2019, 11, 1549931. [CrossRef]

131. Papapanou, P.N.; Sanz, M.; Buduneli, N.; Dietrich, T.; Feres, M.; Fine, D.H.; Flemmig, T.F.; Garcia, R.; Giannobile, W.V.; Graziani, F.; et al. Periodontitis: Consensus report of workgroup 2 of the 2017 World Workshop on the Classification of Periodontal and Peri-Implant Diseases and Conditions. J. Clin. Periodontol. 2018, 45 (Suppl. 20), S162-S170. [CrossRef]

132. Barbour, S.E.; Ishihara, Y.; Fakher, M.; Al-Darmaki, S.; Caven, T.H.; Shelburne, C.P.; Best, A.M.; Schenkein, H.A.; Tew, J.G. Monocyte differentiation in localized juvenile periodontitis is skewed toward the dendritic cell phenotype. Infect. Immun. 2002, 70, 2780-2786. [CrossRef] [PubMed]

133. Diaz-Zuniga, J.; Melgar-Rodriguez, S.; Alvarez, C.; Monasterio, G.; Benitez, A.; Ciuchi, P.; Diaz, C.; Mardones, J.; Escobar, A.; Sanz, M.; et al. T-lymphocyte phenotype and function triggered by Aggregatibacter actinomycetemcomitans is serotype-dependent. J. Periodontal Res. 2015, 50, 824-835. [CrossRef] [PubMed]

134. Nicu, E.A.; Loos, B.G. Polymorphonuclear neutrophils in periodontitis and their possible modulation as a therapeutic approach. Periodontology 2000 2016, 71, 140-163. [CrossRef] [PubMed]

135. Tang, G.; Kawai, T.; Komatsuzawa, H.; Mintz, K.P. Lipopolysaccharides mediate leukotoxin secretion in Aggregatibacter actinomycetemcomitans. Mol. Oral Microbiol. 2012, 27, 70-82. [CrossRef]

136. Ahlstrand, T.; Torittu, A.; Elovaara, H.; Valimaa, H.; Pollanen, M.T.; Kasvandik, S.; Hogbom, M.; Ihalin, R. Interactions between the Aggregatibacter actinomycetemcomitans secretin HofQ and host cytokines indicate a link between natural competence and interleukin-8 uptake. Virulence 2018, 9, 1205-1223. [CrossRef]

137. Paino, A.; Tuominen, H.; Jaaskelainen, M.; Alanko, J.; Nuutila, J.; Asikainen, S.E.; Pelliniemi, L.J.; Pollanen, M.T.; Chen, C.; Ihalin, R. Trimeric form of intracellular ATP synthase subunit beta of Aggregatibacter actinomycetemcomitans binds human interleukin-1beta. PLoS ONE 2011, 6, e18929. [CrossRef] 
138. Ahlstrand, T.; Tuominen, H.; Beklen, A.; Torittu, A.; Oscarsson, J.; Sormunen, R.; Pollanen, M.T.; Permi, P.; Ihalin, R. A novel intrinsically disordered outer membrane lipoprotein of Aggregatibacter actinomycetemcomitans binds various cytokines and plays a role in biofilm response to interleukin-1beta and interleukin-8. Virulence 2017, 8, 115-134. [CrossRef]

139. Paino, A.; Lohermaa, E.; Sormunen, R.; Tuominen, H.; Korhonen, J.; Pollanen, M.T.; Ihalin, R. Interleukin-1beta is internalised by viable Aggregatibacter actinomycetemcomitans biofilm and locates to the outer edges of nucleoids. Cytokine 2012, 60, 565-574. [CrossRef]

140. Paino, A.; Ahlstrand, T.; Nuutila, J.; Navickaite, I.; Lahti, M.; Tuominen, H.; Valimaa, H.; Lamminmaki, U.; Pollanen, M.T.; Ihalin, R. Identification of a novel bacterial outer membrane interleukin-1Beta-binding protein from Aggregatibacter actinomycetemcomitans. PLoS ONE 2013, 8, e70509. [CrossRef]

141. Kanangat, S.; Postlethwaite, A.; Cholera, S.; Williams, L.; Schaberg, D. Modulation of virulence gene expression in Staphylococcus aureus by interleukin-1beta: Novel implications in bacterial pathogenesis. Microbes Infect. 2007, 9, 408-415. [CrossRef] [PubMed]

142. Wu, M.; Guina, T.; Brittnacher, M.; Nguyen, H.; Eng, J.; Miller, S.I. The Pseudomonas aeruginosa proteome during anaerobic growth. J. Bacteriol. 2005, 187, 8185-8190. [CrossRef] [PubMed]

143. Mahdavi, J.; Royer, P.J.; Sjolinder, H.S.; Azimi, S.; Self, T.; Stoof, J.; Wheldon, L.M.; Brannstrom, K.; Wilson, R.; Moreton, J.; et al. Pro-inflammatory cytokines can act as intracellular modulators of commensal bacterial virulence. Open Biol. 2013, 3, 130048. [CrossRef] [PubMed]

144. Sperandio, V.; Torres, A.G.; Kaper, J.B. Quorum sensing Escherichia coli regulators B and C (QseBC): A novel two-component regulatory system involved in the regulation of flagella and motility by quorum sensing in E. coli. Mol. Microbiol. 2002, 43, 809-821. [CrossRef] [PubMed]

145. Moreira, C.G.; Sperandio, V. The Epinephrine/Norepinephrine/Autoinducer-3 Interkingdom Signaling System in Escherichia coli O157:H7. Adv. Exp. Med. Biol. 2016, 874, 247-261. [CrossRef] [PubMed]

146. Weigel, W.A.; Demuth, D.R.; Torres-Escobar, A.; Juarez-Rodriguez, M.D. Aggregatibacter actinomycetemcomitans QseBC is activated by catecholamines and iron and regulates genes encoding proteins associated with anaerobic respiration and metabolism. Mol. Oral Microbiol. 2015, 30, 384-398. [CrossRef]

147. Novak, E.A.; Shao, H.; Daep, C.A.; Demuth, D.R. Autoinducer-2 and QseC control biofilm formation and in vivo virulence of Aggregatibacter actinomycetemcomitans. Infect. Immun. 2010, 78, 2919-2926. [CrossRef]

148. Deatherage, B.L.; Cookson, B.T. Membrane vesicle release in bacteria, eukaryotes, and archaea: A conserved yet underappreciated aspect of microbial life. Infect. Immun. 2012, 80, 1948-1957. [CrossRef]

149. Uhlin, B.E.; Oscarsson, J.; Wai, S.N. Haemolysins. In Pathogenic Escherichia Coli: Molecular and Cellular Microbiology; Morabito, S., Ed.; Caister Academic Press: Norfolk, UK, 2014; pp. 161-180.

150. Rompikuntal, P.K.; Thay, B.; Khan, M.K.; Alanko, J.; Penttinen, A.M.; Asikainen, S.; Wai, S.N.; Oscarsson, J. Perinuclear localization of internalized outer membrane vesicles carrying active cytolethal distending toxin from Aggregatibacter actinomycetemcomitans. Infect. Immun. 2012, 80, 31-42. [CrossRef]

151. Demuth, D.R.; James, D.; Kowashi, Y.; Kato, S. Interaction of Actinobacillus actinomycetemcomitans outer membrane vesicles with HL60 cells does not require leukotoxin. Cell. Microbiol. 2003, 5, 111-121. [CrossRef]

152. Goulhen, F.; Hafezi, A.; Uitto, V.J.; Hinode, D.; Nakamura, R.; Grenier, D.; Mayrand, D. Subcellular localization and cytotoxic activity of the GroEL-like protein isolated from Actinobacillus actinomycetemcomitans. Infect. Immun. 1998, 66, 5307-5313. [PubMed]

153. Karched, M.; Ihalin, R.; Eneslätt, K.; Zhong, D.; Oscarsson, J.; Wai, S.N.; Chen, C.; Asikainen, S.E. Vesicle-independent extracellular release of a proinflammatory outer membrane lipoprotein in free-soluble form. BMC Microbiol. 2008, 8, 18. [CrossRef] [PubMed]

154. Kieselbach, T.; Zijnge, V.; Granström, E.; Oscarsson, J. Proteomics of Aggregatibacter actinomycetemcomitans Outer Membrane Vesicles. PLoS ONE 2015, 10, e0138591. [CrossRef] [PubMed]

155. Kieselbach, T.; Oscarsson, J. Dataset of the proteome of purified outer membrane vesicles from the human pathogen Aggregatibacter actinomycetemcomintans. Data Brief 2017, 10, 426-431. [CrossRef] [PubMed]

156. Rochester, D.F. Does respiratory muscle rest relieve fatigue or incipient fatigue? Am. Rev. Respir. Dis. 1988, 138, 516-517. [CrossRef]

157. Iino, Y.; Hopps, R.M. The bone-resorbing activities in tissue culture of lipopolysaccharides from the bacteria Actinobacillus actinomycetemcomitans, Bacteroides gingivalis and Capnocytophaga ochracea isolated from human mouths. Arch. Oral Biol. 1984, 29, 59-63. [CrossRef] 
158. Reddi, K.; Meghji, S.; Wilson, M.; Henderson, B. Comparison of the osteolytic activity of surface-associated proteins of bacteria implicated in periodontal disease. Oral Dis. 1995, 1, 26-31. [CrossRef]

159. Choi, J.W.; Kim, S.C.; Hong, S.H.; Lee, H.J. Secretable Small RNAs via Outer Membrane Vesicles in Periodontal Pathogens. J. Dent. Res. 2017, 96, 458-466. [CrossRef]

160. O'Donoghue, E.J.; Krachler, A.M. Mechanisms of outer membrane vesicle entry into host cells. Cell. Microbiol. 2016, 18, 1508-1517. [CrossRef]

161. Kesty, N.C.; Mason, K.M.; Reedy, M.; Miller, S.E.; Kuehn, M.J. Enterotoxigenic Escherichia coli vesicles target toxin delivery into mammalian cells. EMBO J. 2004, 23, 4538-4549. [CrossRef]

162. Nice, J.B.; Balashova, N.V.; Kachlany, S.C.; Koufos, E.; Krueger, E.; Lally, E.T.; Brown, A.C. Aggregatibacter actinomycetemcomitans Leukotoxin Is Delivered to Host Cells in an LFA-1-Indepdendent Manner When Associated with Outer Membrane Vesicles. Toxins 2018, 10, 414. [CrossRef] [PubMed]

163. Ximenez-Fyvie, L.A.; Haffajee, A.D.; Socransky, S.S. Microbial composition of supra- and subgingival plaque in subjects with adult periodontitis. J. Clin. Periodontol. 2000, 27, 722-732. [CrossRef] [PubMed]

164. Noiri, Y.; Li, L.; Ebisu, S. The localization of periodontal-disease-associated bacteria in human periodontal pockets. J. Dent. Res. 2001, 80, 1930-1934. [CrossRef] [PubMed]

165. Christersson, L.A.; Albini, B.; Zambon, J.J.; Wikesjo, U.M.; Genco, R.J. Tissue localization of Actinobacillus actinomycetemcomitans in human periodontitis. I. Light, immunofluorescence and electron microscopic studies. J. Periodontol. 1987, 58, 529-539. [CrossRef] [PubMed]

166. Colombo, A.V.; da Silva, C.M.; Haffajee, A.; Colombo, A.P. Identification of intracellular oral species within human crevicular epithelial cells from subjects with chronic periodontitis by fluorescence in situ hybridization. J. Periodontal Res. 2007, 42, 236-243. [CrossRef]

167. Mendes, L.; Rocha, R.; Azevedo, A.S.; Ferreira, C.; Henriques, M.; Pinto, M.G.; Azevedo, N.F. Novel strategy to detect and locate periodontal pathogens: The PNA-FISH technique. Microbiol. Res. 2016, 192, 185-191. [CrossRef]

168. Willi, M.; Belibasakis, G.N.; Bostanci, N. Expression and regulation of triggering receptor expressed on myeloid cells 1 in periodontal diseases. Clin. Exp. Immunol. 2014, 178, 190-200. [CrossRef]

169. Thurnheer, T.; Belibasakis, G.N. Integration of non-oral bacteria into in vitro oral biofilms. Virulence 2015, 6, 258-264. [CrossRef]

170. Bao, K.; Bostanci, N.; Selevsek, N.; Thurnheer, T.; Belibasakis, G.N. Quantitative proteomics reveal distinct protein regulations caused by Aggregatibacter actinomycetemcomitans within subgingival biofilms. PLoS ONE 2015, 10, e0119222. [CrossRef]

171. Llama-Palacios, A.; Potupa, O.; Sanchez, M.C.; Figuero, E.; Herrera, D.; Sanz, M. Aggregatibacter actinomycetemcomitans Growth in Biofilm versus Planktonic State: Differential Expression of Proteins. J. Proteome Res. 2017, 16, 3158-3167. [CrossRef]

172. Costerton, J.W.; Stewart, P.S.; Greenberg, E.P. Bacterial biofilms: A common cause of persistent infections. Science 1999, 284, 1318-1322. [CrossRef] [PubMed]

173. Rathsam, C.; Eaton, R.E.; Simpson, C.L.; Browne, G.V.; Berg, T.; Harty, D.W.; Jacques, N.A. Up-regulation of competence- but not stress-responsive proteins accompanies an altered metabolic phenotype in Streptococcus mutans biofilms. Microbiology 2005, 151, 1823-1837. [CrossRef] [PubMed]

174. Takasaki, K.; Fujise, O.; Miura, M.; Hamachi, T.; Maeda, K. Porphyromonas gingivalis displays a competitive advantage over Aggregatibacter actinomycetemcomitans in co-cultured biofilm. J. Periodontal Res. 2013, 48, 286-292. [CrossRef] [PubMed]

175. Smith, K.P.; Voogt, R.D.; Ruiz, T.; Mintz, K.P. The conserved carboxyl domain of MorC, an inner membrane protein of Aggregatibacter actinomycetemcomitans, is essential for membrane function. Mol. Oral Microbiol. 2016, 31, 43-58. [CrossRef] [PubMed]

176. Smith, K.P.; Fields, J.G.; Voogt, R.D.; Deng, B.; Lam, Y.W.; Mintz, K.P. Alteration in abundance of specific membrane proteins of Aggregatibacter actinomycetemcomitans is attributed to deletion of the inner membrane protein MorC. Proteomics 2015, 15, 1859-1867. [CrossRef]

177. Zijnge, V.; Kieselbach, T.; Oscarsson, J. Proteomics of protein secretion by Aggregatibacter actinomycetemcomitans. PLOS ONE 2012, 7, e41662. [CrossRef]

178. Rylev, M.; Abduljabar, A.B.; Reinholdt, J.; Ennibi, O.K.; Haubek, D.; Birkelund, S.; Kilian, M. Proteomic and immunoproteomic analysis of Aggregatibacter actinomycetemcomitans JP2 clone strain HK1651. J. Proteom. 2011, 74, 2972-2985. [CrossRef] 
179. Tendeng, C.; Bertin, P.N. H-NS in Gram-negative bacteria: A family of multifaceted proteins. Trends Microbiol. 2003, 11, 511-518. [CrossRef]

180. Juarez, A.; Nieto, J.M.; Prenafeta, A.; Miquelay, E.; Balsalobre, C.; Carrascal, M.; Madrid, C. Interaction of the nucleoid-associated proteins Hha and H-NS to modulate expression of the hemolysin operon in Escherichia coli. Adv. Exp. Med. Biol. 2000, 485, 127-131. [CrossRef]

181. Li, H.; Granat, A.; Stewart, V.; Gillespie, J.R. RpoS, H-NS, and DsrA influence EHEC hemolysin operon (ehxCABD) transcription in Escherichia coli O157:H7 strain EDL933. FEMS Microbiol. Lett. 2008, 285, 257-262. [CrossRef]

182. Wang, H.; Ayala, J.C.; Benitez, J.A.; Silva, A.J. RNA-seq analysis identifies new genes regulated by the histone-like nucleoid structuring protein (H-NS) affecting Vibrio cholerae virulence, stress response and chemotaxis. PLoS ONE 2015, 10, e0118295. [CrossRef] [PubMed]

183. Bao, K.; Belibasakis, G.N.; Selevsek, N.; Grossmann, J.; Bostanci, N. Proteomic profiling of host-biofilm interactions in an oral infection model resembling the periodontal pocket. Sci. Rep. 2015, 5, 15999. [CrossRef] [PubMed]

184. Maughan, H.S.S.; Wilson, L.; Redfield, R. Competence, DNA Uptake and Transformation in Pasteurellaceae. In Pasteurellaceae Biology, Genomics and Molecular Aspects; Kuhnert, P., Christensen, H., Eds.; Caister Academic Press: Norfolk, UK, 2008; pp. 79-88.

185. Fujise, O.; Lakio, L.; Wang, Y.; Asikainen, S.; Chen, C. Clonal distribution of natural competence in Actinobacillus actinomycetemcomitans. Oral Microbiol. Immunol. 2004, 19, 340-342. [CrossRef] [PubMed]

186. Jorth, P.; Whiteley, M. An evolutionary link between natural transformation and CRISPR adaptive immunity. mBio 2012, 3. [CrossRef]

187. Redfield, R.J.; Findlay, W.A.; Bosse, J.; Kroll, J.S.; Cameron, A.D.; Nash, J.H. Evolution of competence and DNA uptake specificity in the Pasteurellaceae. BMC Evol. Biol. 2006, 6, 82. [CrossRef]

188. Wang, Y.; Shi, W.; Chen, W.; Chen, C. Type IV pilus gene homologs pilABCD are required for natural transformation in Actinobacillus actinomycetemcomitans. Gene 2003, 312, 249-255. [CrossRef]

189. Tanaka, A.; Fujise, O.; Chen, C.; Miura, M.; Hamachi, T.; Maeda, K. A novel gene required for natural competence in Aggregatibacter actinomycetemcomitans. J. Periodontal Res. 2012, 47, 129-134. [CrossRef]

190. Hisano, K.; Fujise, O.; Miura, M.; Hamachi, T.; Matsuzaki, E.; Nishimura, F. The pga gene cluster in Aggregatibacter actinomycetemcomitans is necessary for the development of natural competence in $\mathrm{Ca}^{2+}$-promoted biofilms. Mol. Oral Microbiol. 2014, 29, 79-89. [CrossRef]

191. Wang, Y.; Goodman, S.D.; Redfield, R.J.; Chen, C. Natural transformation and DNA uptake signal sequences in Actinobacillus actinomycetemcomitans. J. Bacteriol. 2002, 184, 3442-3449. [CrossRef] 